\title{
Oil Discoveries and Protectionism: Role of News Effects ${ }^{\S}$
}

\author{
Fidel Perez-Sebastian*, Ohad Raveh ${ }^{* *}$, Frederick van der Ploeg ${ }^{* * *}$
}

\begin{abstract}
Can oil discovery shocks affect the demand for protectionism? An intertemporal model of Dutch disease indicates that if the tradable sector is politically dominant then an oil discovery can induce protectionism. If the economy is also credit constrained, this effect is intensified upon discovery, but partially reversed when oil revenues start to flow. We test these predictions using 16.2 million, HS-6 level, bilateral tariff rates that cover 5,718 products in 155 countries over the period 1988-2012, and data on worldwide discoveries of giant oil and gas fields. Our identification strategy rests on the exogeneity of the timing of discoveries. Our empirical results indicate that an oil discovery increases tariffs during pre-production years and decreases tariffs in the years to follow yet to a lesser extent, most notably in capital scarce economies with a relatively dominant tradable sector. Our baseline estimates indicate that a giant oil field discovery induces a rise of approximately $13 \%$ in the average tariff over the course of 10 years; this increase is approximately 2.5 times larger during the pre-production period when the oil discovery represents a pure news shock.
\end{abstract}

Keywords: Oil discoveries, protectionism, capital scarcity, Dutch disease, political economy, trade policy, news shocks

JEL codes: Q32, F13, O24

Revised August 2020

\footnotetext{
$\S$ We are grateful for the constructive comments and advice of three anonymous referees and the editor on an earlier version of this paper. We have also benefited from helpful comments received from Jim Cust and David Mihalyi and from participants at the EARE Conference, Manchester, 2019, the $5^{\text {th }}$ International Workshop on Economic Growth, Environment and Natural Resources, European University Workshop, Saint Petersburg, 2019, the Mundlak Workshop, Hebrew University, 2019, the (virtual) EARE Conference, 2020, and at seminars at UPO, Seville and the University of Economics, Prague.

* Department

of Economics, University of Alicante, and University of Hull. Email: fidel.perez@ua.es.

** Department of Environmental Economics and Management, Hebrew University of Jerusalem. Email: ohad.raveh@mail.huji.ac.il.

*** Department of Economics, University of Oxford. Email: rick.vanderploeg@economics.ox.ac.uk. Also affiliated with VU University Amsterdam, CEPR and CESifo.
} 


\section{Introduction}

Understanding the determinants of protectionism has been a long-standing interest of economists and policy makers. ${ }^{1}$ Recently, populist politicians in various countries have called for a reduction in the level of globalisation. The desire to raise protectionism in periods of negative or slow growth is not new. Since the last global financial crises, it has even manifested itself in economies that historically have strongly endorsed free trade. ${ }^{2}$ While a range of determinants for protectionism varying from workers that have been suffered from globalisation to protection lobbies has been put forward, the potential role of oil discoveries has received relatively little attention. This is surprising because the anticipation and wealth effects induced by major oil discoveries have significant impacts on the tradable sectors of small open economies. ${ }^{3}$ Our aim is to explore the role of oil discoveries in inducing protectionism. We provide theoretical foundations and empirical evidence for the impact of oil discoveries on the level of tariffs, illustrating that such discoveries can lead to economically significant higher levels of protectionism. Furthermore, we show that these effects depend on the extent of financial constraints, dominance of the tradable sector, and whether the policy decision is made before or after the discovery entered its production phase.

The latter point provides further motivation for our work. Following the seminal ideas in Pigou (1927) and Keynes (1936), the literature has explored how expectations and news shocks about possible future events are important in the decisions made by forward-looking agents and how they affect macroeconomic outcomes. ${ }^{4}$ Although attention has focused on quantification of the effects of news shocks on the consumption and investment decisions made by private agents and their effect on macroeconomic outcomes, less attention has been devoted to the impact of news shocks on the design of policy. ${ }^{5}$ Notably, private and public agents' behaviours are not driven by the same goals (e.g. Pritchett, 2000; Besley and Burgess, 2002). Hence, the response of the latter to news shocks should be studied separately. We address this shortcoming by focusing on the role of oil discoveries in determining tariff policies. This allows us to distinguish between the impact before and after production

\footnotetext{
${ }^{1}$ See, e.g., Costinot et al. (2015), and Gawande and Krishna (2008), and references therein.

${ }^{2}$ One example is the U.S. Specifically, the U.S. President Donald Trump recently claimed that protectionism leads to greater prosperity (Trump, 2017). Indeed, the 2018 wave of tariff rate increases in the U.S. represents the most comprehensive protectionist trade policies implemented there since 1971 (Fajgelbaum et al., 2019).

${ }^{3}$ Recent studies that support this view include Arezki et al. (2017) and Harding et al. (2020). More generally, the vast literature on the Dutch disease mechanism (e.g. Corden and Neary, 1982), which highlights that resource booms induce appreciation of the real exchange rate that contracts the tradable sectors, points at similar directions (see van der Ploeg (2011) for a survey of the related literature).

${ }^{4}$ More specifically, the literature has mainly explored quantitatively the contribution of news shocks to observed business cycle fluctuations in environments in which the private sector forms estimates about the future based on different sources of information. This literature includes closed economy models (e.g. Beaudry and Portier, 2014), for a review), open economy setups, like Jaimovich and Rebelo (2009), and time series analyses such as Beaudry and Portier (2006) and Barsky et al. (2014), among others. Other works have focused on their effects of news shocks on the current account immediately after a giant oil discovery and after oil production finally takes place (see, e.g., Arezki et al. (2017), for a review).

${ }^{5}$ Some exceptions include, for example, Lorenzoni (2010) and Gambetti (2019), which explore the effects of news shocks on monetary policy, and Bianchi et al. (2016) that studies their impact on macroprudential policy.
} 
has started. The anticipation effects induced in the former period, as noted by Arezki et al. (2017), can be considered as pure news shocks. Exploiting this feature, we find that news shocks associated with oil discoveries have an important role in inducing the temporal pattern of protectionist policies.

Our analysis focuses on tariffs. As Ludema et al. (2010) and Furceri et al. (2018), among others, argue, tariffs are a good variable for studying trade policy. First, tariffs are the preferred protectionist instrument for many governments and are easy to measure. Second, they are often changed and modified, even in countries that are members of the World Trade Organisation (WTO). This, in turn, gives the necessary variability for identification purposes. In the United States, for example, Congress regularly passes Miscellaneous Tariff Bills, each containing hundreds of changes to the harmonised tariff schedule. Third, tariff changes represent discretionary policies that are much less internationally constrained than other trade policies. The only rule for WTO members is that they do not raise their tariffs above their bound rates.

We start by providing foundations for the effect of oil discoveries on tariff formation. We present a two-period model of Dutch disease in which the government can borrow from the rest of the world and tariffs are endogenously determined. If access to global capital markets is imperfect, a premium on foreign debt must be paid. The government welfare function is a weighted sum of the utilities obtained by the three different groups in society (cf. Long and Vousden, 1991). Each of these three groups owns a different input: tradable-sector-specific capital, non-tradable-sector-specific capital, and labour. We show the impact of an unanticipated oil discovery on tariffs, before and after oil extraction starts, and under different credit conditions. Before the oil-extraction stage, the oil discovery constitutes a pure news shock. We show that if the government objective function attaches equal utility weights to capital owners in each sector and to wage earners (in which case the government maximises aggregate Hicksian consumption) zero tariffs are the optimal outcome. But, if the government wants to protect the interests of capital owners in the traded industry against the adverse effects of Dutch disease, it chooses to impose a positive tariff even ahead of the windfall, upon news of the oil discovery, and to smooth consumption and the tariff via judicious debt management over time. If the economy is credit constrained and debt management is hampered, the government puts up a higher tariff in the announcement period than during the windfall period and partially lowers the tariff once oil production starts.

We econometrically test these predictions using detailed bilateral tariff data. The sample includes 16.2 million HS-6 level tariff rates that cover 5,718 products in 155 countries over the period 1988-2012. As a measure of the wealth windfall, we employ worldwide discoveries of giant oil and gas fields. Our identification strategy plausibly assumes that the timing of discoveries is exogenous. The unique feature of these data enables us to distinguish between pre- and post-production periods. Using the methodology proposed by Arezki et al. (2017), we find empirically that an oil discovery increases tariffs during pre-production years and decreases tariffs in the years to follow but to a lesser extent, most notably in capital scarce economies with a relatively dominant tradable sector. This suggests that news 
about oil discoveries increase protectionism. We perform several robustness exercises and find that these results are remarkably robust. They are also quantitatively large: our baseline estimates indicate that a giant oil field discovery induces an increase of approximately 13\% (1.4 percentage points) in the average tariff over the course of 10 years, and almost 2.5 times this amount during the pre-production period. Specifically, during the pre-production period the average tariff increases by about $34 \%$ (3.75 percentage points), while during the post-production period it decreases by about $21 \%$ (2.35 percentage points).

The paper contributes to several additional strands of literature. First, we develop novel political economy implications of the Dutch disease. Corden and Neary (1982) highlighted the potential negative impact of a natural resource discovery on the tradable industries due to appreciation of the real exchange rate. Recent empirical studies indicate that the various aspects of this mechanism gain support in crosscountry data (e.g. Arezki et al., 2017; Harding et al., 2020). While the use of tariffs to ameliorate Dutch disease effects has been noted before, to our best knowledge there has not been any attempt to study empirically its mechanisms, direction and magnitude. ${ }^{6}$ Our aim is to fill this gap and show that it is optimal to react to an oil discovery by raising tariffs, especially during the period after the discovery but before oil production has started. Furthermore, our results show that in capital-constrained economies tariffs help to compensate the lack of effective debt management to smooth consumption.

Second, we contribute to the literature on the political economy determinants of tariff policy. ${ }^{7}$ Since Adam Smith (1776), most orthodox economists support free trade as the preferred scenario. According to this view, many of the observed barriers to international trade are the result of policymakers that do not maximise social welfare. One explanation is that protectionism is due to vested interests in the political marketplace (e.g. Grossman and Helpman, 1994). Notably, this literature has largely focused on explaining why protectionism rises during bad periods, in contrast to recent occurrences (e.g. Trump, 2017). ${ }^{8}$ Our contribution is twofold. First, we study the role of an additional determinant (while accounting for the key tariff determinants noted in previous related studies (e.g., Lake and Linask, 2017)), i.e. the news effects of oil discoveries. Second, we provide new insights concerning the desire to raise the extent of protectionism during good periods.

The latter point relates to an additional strand of literature on the association between tariffs and the business cycle. Lake and Linask (2017) give evidence that tariffs are procyclical if they are motivated by terms of trade effects. They argue that economic expansions may lead to a stronger power of

\footnotetext{
${ }^{6}$ Collier and Venables (2011) consider the illusory nature of tariff revenues in trade policies of resource-rich economies. Our framework differs by accounting for Dutch disease, optimal tariffs, and anticipation effects in an intertemporal context as well as by considering more explicitly the role of political distortions. Due to the presence of a non-traded sector in our model, the real revenue from import tariffs is no longer illusory.

${ }^{7}$ McLaren (2016) provides a review of this literature.

${ }^{8}$ This perspective also extends to the broader literature on the determinants of tariffs (e.g., Daudin et al., 2011; Gawande et al., 2011; Gawande and Krishna, 2008; Magee and Magee, 2010; Yasar, 2013).
} 
importers on product markets, and then, under the terms of trade hypothesis (e.g. Nicita et al., 2018; Ludema and Mayda, 2013), to higher optimal tariffs that reduce world demand and prices for the imported goods, thus improving the country's terms of trade. Our analysis is complementary to this terms-of-trade perspective. ${ }^{9}$ We propose a novel mechanism that also helps explain why tariffs can increase when the economy enjoys a windfall of income.

Finally, our paper is also related to the literature on booms, rent seeking and economic growth, although our goal and approach are very different. For example, income booms can generate politically-driven rent-seeking behaviour that can hurt economic growth (e.g. Tornell and Lane, 1999; Mehlum et al., 2006). In our model, the government's efforts to favour exporters can also be attributed to rent seeking. However, the rents extracted by these exporters are a consequence of higher prices in domestic markets instead of a direct expropriation of income from the booming sector. Our goal is also different, because we focus on the impact of the shocks on tariff choice rather than on economic growth. ${ }^{10}$

Section 2 motivates our analysis with examples of four countries. Section 3 presents and develops predictions from our analytical model. Section 4 presents our data and baseline empirical results including tests for the potential mechanism of our results. Section 5 presents econometric analysis of heterogeneous and sectoral effects of oil discoveries on tariff changes. It also offers robustness tests with respect to the timing of discoveries and production, and a range of further robustness tests. Section 6 concludes.

\section{Motivation: Oman, Peru, Philippines, and Thailand}

As an initial step, we examine the cases of four economies, namely Oman, Peru, Philippines, and Thailand, to illustrate the potential link between giant oil discoveries and protectionist policies. We focus on these four economies because each experienced a single giant oil discovery over our sample period and has sufficient tariff data. This allows us to undertake a simple descriptive event study for each case. ${ }^{11}$ In Figure 1, we plot in separate panels for each of these countries the evolution of the average tariff rate over 15 years. The vertical dashed lines represent the year of the discovery, and the timeframe starts four years prior to the discovery and continues up to ten years after it. ${ }^{12}$

\footnotetext{
${ }^{9}$ Specifically, in our framework the prices of exports and importables are exogenous, and the discovery-induced effect on the real exchange rate is driven by changes in the price of domestic goods, rather than by changes in the terms of trade.

${ }^{10}$ Caselli and Michaels (2013) emphasise the importance of rent-seeking activities related to oil revenues, but do not analyse trade policy.

${ }^{11}$ A descriptive effort, which excludes further controls, is less effective in cases with multiple discoveries over the period examined (15 years), because disentangling their effect is not straightforward. In our sample, there are, overall, eight economies that experienced a single discovery over a prolonged period, out of which only the four examined have sufficient data to undertake a complete pre-post discovery mapping of average tariff rates.

12 This timeframe is consistent with the one we adopt in the empirical analysis, where we will motivate its choice.
} 
Several common features are observed across the panels. First, the average tariff increases around the time of the discovery, remains above its mean in the years to follow, and even experiences further increases in some cases. Second, about four years after the discovery, the average tariff starts depicting a clear decreasing pattern. Third, ten years past the discovery, the average tariff in all cases either returns to its pre-discovery level or remains slightly higher. Importantly, these patterns emerge despite the exclusion of further controls, most notably those related to the general trend for globalisation. In the empirical part, we show that these patterns generalise under an extended sample and a rigorous analysis; thus, illustrating that, if other determinants such as globalisation are held constant, oil discoveries have an overall positive impact on the average tariff rate.

An additional feature relates to the trade balance of products that drive the observed post-discovery rise. The steepest post-discovery tariff increases occur in textiles and plastics for Oman, textiles, machinery and mechanical appliances for Peru, textiles, machinery and transportation for the Philippines, and textiles, machinery and metals for Thailand. A more detailed examination of the HS-6 level products in which the increases appear most strongly reveals a favourable (positive) trade balance in the vast majority of product lines that compose the abovementioned industries in each of the four countries. This suggests that the demand for protectionism is driven by exporters. In addition, all four countries have above average values, of more than one standard deviation in some cases, in our measures of credit constraints and the dominance of their tradable sectors (described in more detail in the empirical part). The model we layout in the next section rationalises these descriptive patterns, and the empirical analysis that follows illustrates that these observations gain support under a more general sample.

Finally, Appendix F also considers two additional examples of economies with multiple discoveries, i.e. Malaysia and Indonesia. Given the consecutive nature of their discoveries, the description of their cases is more anecdotal. Nonetheless, both countries exhibit similar patterns to those noted above and highlight further features that relate to the political aspects of the framework that we propose next.

Figure 1: Average tariffs in Oman, Peru, Philippines, and Thailand
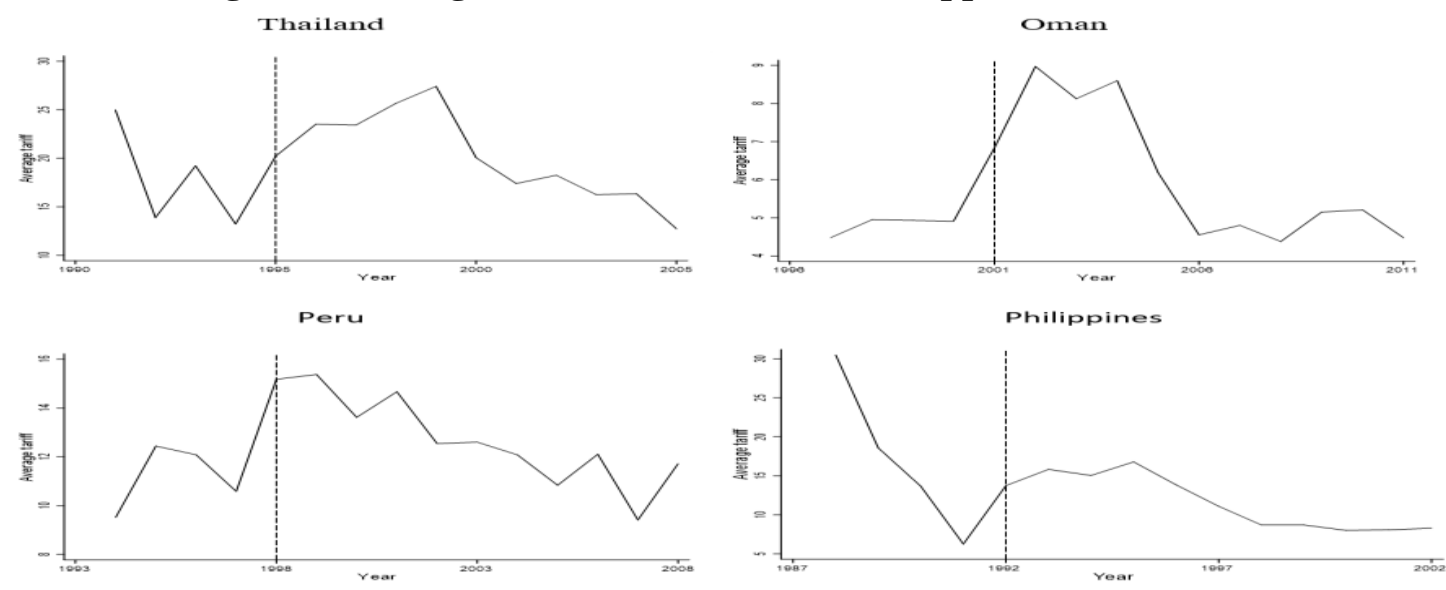

Notes: Figure plots the average annual ad-valorem tariffs in Oman, Peru, Philippines, and Thailand, four years prior to a giant oil discovery, and up to ten years after it. Dashed lines represent the discovery year. (Sources: Horn (2014), WITS-TRAINS). 


\section{Political Economy of Tariffs and Anticipated Oil Windfalls}

Here we demonstrate that a tariff on imports of tradables can be attractive for governments that want to protect the interests of capital owners in the traded sector more than the interests of workers and other capital owners in face of Dutch disease effects stemming from an oil windfall. To get a better understanding of these issues, we distinguish three groups in the economy: capital owners in the traded sector, capital owners in the non-tradable sector, and workers. A politically neutral analysis gives consumption of each group equal weight, but we are interested in the case where the capital owners in the traded sector have more lobby power in the face of adverse Dutch disease effects on their sector than capital owners in the non-traded sector and workers. It is this assumption which leads to a demand for protectionism and governments levying positive tariffs. In addition, we show that the chosen tariff is implemented upon news of the oil discovery even before oil extraction begins, yet is partially reversed once oil production begins and oil revenues start to flow if the country faces capital scarcity and has to pay an interest premium on foreign debt. It is the assumption of imperfect capital markets that leads to partial reversal of the increase in tariffs, because it does not allow for perfect consumption smoothing.

\subsection{A three-goods model of Dutch disease and tariffs}

To get immediate effects on welfare and facilitate tractable results, our model uses the duality approach and the GNP function first used by Neary (1988) to analyse Dutch disease in a very elegant fashion. Our model has three novel features. First, it is an intertemporal two-period extension of the duality approach to Dutch disease developed by Neary (1988). This allows us to analyse saving, international borrowing and the current account. Duality is used to back out effects on welfare (both in each period and on the present discounted value of utilities). Second, our model allows for imperfect access to capital markets and an interest premium on debt. This was an important feature of the one-sector analysis of optimal management of natural resource windfalls developed by van der Ploeg and Venables (2011). Here it will be an important factor in explaining why tariff increases are partially reversed when oil and gas production start. Third, in line with Long and Vousden (1991) our model introduces political economy features and assumes that the government favours certain groups in society more than others. In fact, we assume that the government gives a relatively high weight to capital owners in the tradables sector since these are most hurt by Dutch disease effects. This explains why the government succumbs to the demand for protectionism and levies tariffs when news of an oil and gas discovery comes in.

Consider a small open economy which consumes tradables and non-tradables, both produced at home, and importables which are infinitely elastically supplied at an exogenous world price $q \cdot{ }^{13}$ The world price of tradables is normalised to 1 and the price of non-tradables is denoted by $p$. Imports of tradables face an ad valorem tariff $\tau$, so that domestic consumers face a price $1+\tau$. The three goods are imperfect substitutes in consumption. Consumer demand is homothetic. Rents in the traded and non-traded sectors

\footnotetext{
${ }^{13}$ We have foreign-produced importables; else, imports of tradables would just equal oil revenue.
} 
accrue to a specific fixed factor, say capital, as in the Ricardo-Viner model. ${ }^{14}$ Total labour supply is fixed and moves freely between the domestic sectors, but not internationally.

Consumer expenditure is given by: $e(p, \tau, q) c=p c^{N}+(1+\tau) c^{T}+q m$, where $c$ denotes Hicksian consumption, $c^{N}$ and $c^{T}$ are consumption of non-tradable and tradable goods, respectively, and $e($. denotes the unit-expenditure function. As usual, this last function is homogeneous of degree one in prices. Consumption of non-tradables, tradables and importables can be obtained from Shephard's lemma as $c^{N}=e_{p} c, c^{T}=e_{\tau} c$ and $m=e_{q} c$, respectively. Household utility is $u\left(c^{N}, c^{T}, m\right)=c$.

Each sector operates under perfect competition and constant returns to scale. Producers of non-tradables choose employment $l^{N}$ to maximise short-run profits $\pi^{N}=p f\left(k^{N}, l^{N}\right)-w l^{N}$, where $k^{N}$ denotes sector-specific capital, $w$ the wage and $f^{N}($.) the concave production function. Labour demand follows from setting the marginal product of labour to wage costs, $p \partial f^{N} / \partial l^{N}=w$. Similarly, for the traded sector we get $\pi^{T}=(1+\tau) f^{T}\left(k^{T}, l^{T}\right)-w l^{T}$ and $(1+\tau) \partial f^{T} / \partial l^{T}=w$. Labour market equilibrium requires $l^{N}+l^{T}=1$, where exogenous labour supply has without loss of generality been set to unity. Following Neary (1988), we define the GNP function $y(p, \tau)$. This gives the maximum level of GNP with equilibrium on the labour market imposed, i.e. $y=p y^{N}+(1+\tau) y^{T}$, where $y^{N}=y_{P}$ and $y^{T}=y_{\tau}$. The cross derivatives of the GNP function are negative, since reallocation of labour occurs towards the sector whose price is increased. GNP is distributed as profit and wage income, i.e. $y=\pi^{N}+\pi^{T}+w$.

Current account equilibrium requires $c^{T}+q m=y^{T}+n+b$, and non-traded goods market equilibrium requires $c^{N}=y^{N}$, where $y^{T}$ denotes production of tradables, $n$ windfall revenue, and $b$ government borrowing from abroad. ${ }^{15}$ Hence, consumption of importables, qm, plus imports of tradables, $\lambda \equiv c^{T}-y^{T}$, is financed by windfall revenue $n$ or borrowing $b$.

Employing the consumer expenditure function, the conditions for equilibrium on the current account and market clearing in the non-tradable goods market become

$$
\begin{gathered}
e(p, \tau) c=y(p, \tau)+n+b+\tau\left[e_{\tau}(p, \tau) c-y_{\tau}(p, \tau)\right], \\
e_{p}(p, \tau) c=y_{p}(p, \tau),
\end{gathered}
$$

respectively, where for simplicity we set the price of importables $q$ to 1 . We can solve (1) and (2) for $p$ and $c$ in terms of $n, b$ and $\tau$, and thus write all variables in terms of $n, b$ and $\tau$, e.g. $\lambda=\lambda(n, b, \tau)$. To

\footnotetext{
${ }^{14}$ We ignore dynamics of capital stocks and absorption constraints (e.g. van der Ploeg and Venables, 2013).

${ }^{15}$ Private agents do not have access to international capital markets. This does not affect our qualitative results because the consumption smoothing role of debt is already captured through government debt.
} 
gain insight into the comparative statics, we totally differentiate (1) and (2) and obtain the effects of the windfall, debt and tariffs on Hicksian consumption and the relative price of non-tradables:

$$
e d c=\left(1+\tau \lambda_{n}\right) d(n+b)+\tau \lambda_{\tau} d \tau
$$

$$
\frac{d p}{p}=\frac{1}{\varepsilon^{S}+\varepsilon^{N}}\left(\frac{1}{e c}\left[\left(1+\tau \lambda_{n}\right) d(n+b)+\tau \lambda_{\tau} d \tau\right]+\left(\varepsilon^{N C}+\varepsilon^{S C}\right) \frac{d \tau}{1+\tau}\right)
$$

where $\varepsilon^{S} \equiv p y_{p p} / y_{p}>0$ and $\varepsilon^{N} \equiv-p e_{p p} / e_{p}>0$ define the own price elasticities, and $\varepsilon^{S C} \equiv-(1+\tau) y_{p \tau} / y_{p}$ and $\varepsilon^{N C} \equiv(1+\tau) e_{p \tau} / e_{p}$ the cross-price elasticities for supply of non-tradables and the compensated demand for non-tradables, respectively. The supply of non-tradables decreases with the tariff, so $y_{p \tau}<0$ and $\varepsilon^{S C}>0$. We assume that consumption of non-tradables and tradables are Hicksian substitutes, so $e_{p \tau}>0$ and $\varepsilon^{N C}>0$.

The interpretation of equations (3) and (4) is as follows. Without a tariff, a windfall and borrowing from abroad boost Hicksian consumption, $c$. These also raise the price of non-tradables, $p$, and more so if the own price elasticities of supply and compensated demand are large. As a consequence, there is a relocation of labour from the traded to the non-traded sector. Profits in the non-traded sector and wage income rise, but profits in the traded sector decline. Since a windfall boosts import of tradables, $\lambda_{n}>0$, we see from equations (3) and (4) that the effect of the windfall on Hicksian consumption and the price of non-tradables is larger if there is a pre-existing tariff on tradables. Furthermore, since $\lambda_{\tau}<0$, equation (3) establishes that Hicksian consumption is maximised (for a given level of debt $b$ ) if the government sets the tariff to zero. The reason is, of course, that tariffs distort relative prices and depress social welfare, that is, reduce Hicksian consumption defined as the aggregate of real consumption across all groups in society.

Around $\tau=0$ represents an interesting case. The comparative statics of the model then become $\frac{d p}{p}=\frac{1}{\varepsilon^{S}+\varepsilon^{N}}\left(\frac{d(n+b)}{e c}+\left(\varepsilon^{N C}+\varepsilon^{S C}\right) d \tau\right)$ and $d c=d(n+b) / e$. Introducing a small tariff now does not affect Hicksian consumption but does make non-traded production relatively more attractive and boosts the price of non-tradables. This expands non-tradables output and curbs tradables output. This general equilibrium effect offsets some of the beneficial impact of the tariff on profits in the traded sector and some of the adverse effect on profits in the non-traded sector; in addition, it reinforces the positive effect of the tariff on the wage. The tariff, however, does not affect the real value of the sum of 
wage income plus profits of capitalists in the two sectors. Hicksian consumption and thus welfare are unaffected by introducing a small tariff. ${ }^{16}$

\subsection{Income distribution and political economy of tariffs}

Total government revenue consists of windfall and tariff revenue plus borrowing, $s=n+\tau \lambda+b$. There are three competing groups in society: owners of capital in the traded sector receiving profits $\pi^{T}$, owners of capital in the non-traded sector receiving profits $\pi^{N}$, and workers receiving wage income $w$. Shares $\beta^{T}$ and $\beta^{N}$ of public revenue are received by owners of capital in the traded and non-traded sectors and a share $\beta^{W}$ by workers, where $\beta^{T}+\beta^{N}+\beta^{W}=1$. The indirect utilities for the owners of capital in the traded sector, the owners of capital in the non-traded sector, and workers equal $u^{T}=\left(\pi^{T}+\beta^{T} s\right) / e, u^{N}=\left(\pi^{N}+\beta^{N} s\right) / e$, and $u^{W}=\left(y-\pi^{N}-\pi^{T}+\beta^{W} s\right) / e$, respectively. The sum of these utilities is equal to Hicksian consumption, $u^{T}+u^{N}+u^{W}=c$, as total spending is $e c=y+s$.

Following Long and Vousden (1991), the government has the political objective function ${ }^{17}$

$$
\omega \equiv \gamma^{N} u^{N}+\gamma^{T} u^{T}+\gamma^{W} u^{W}=\left(\gamma^{T}\left(\pi^{T}+\beta^{T} s\right)+\gamma^{N}\left(\pi^{N}+\beta^{N} s\right)+\gamma^{W}\left(y-\pi^{N}-\pi^{T}+\beta^{W} s\right)\right) \frac{1}{e},
$$

where $s=n+b+\tau \lambda$ and $c$ and $p$ follow from (3) and (4). The welfare weights $\gamma^{N}, \gamma^{T}$ and $\gamma^{W}$ are normalised so $\gamma^{N}+\gamma^{T}+\gamma^{W}=1$. A politically neutral government sets $\gamma^{N}=\gamma^{T}=\gamma^{W}=1 / 3$ so the government objective (5) boils down to Hicksian consumption, i.e. $\omega=c=(y+s) / e$, and the optimal tariff (given the nation's debt $b$ ) is zero. A politically motivated government gives different welfare weights to the different groups in society. For our purposes, we are interested in governments that are more susceptible to the lobbies of tradable sector capitalists. For example, in the extreme case where the government only cares about utility of traded-sector capitalists (i.e. $\gamma^{T}=1$ and $\gamma^{N}=\gamma^{W}=0$ ), it maximises $\omega=\left(\pi^{T}+\beta^{T} s\right) / e$ taking debt $b$ as given. This gives the optimality condition for the tariff

$$
\frac{\partial \pi^{T}}{\partial \tau}+\beta^{T} \lambda\left(1-\varepsilon^{M} \frac{\tau}{1+\tau}\right)=u^{T} \frac{\partial e}{e \partial \tau} \text { with } \varepsilon^{M} \equiv-\frac{(1+\tau) \partial \lambda}{\lambda \partial \tau}>0
$$

\footnotetext{
${ }^{16}$ In the absence of importables, it can be shown that $e \partial(s / e) / \partial \tau=n\left(p c^{N} / e c\right)$. As the non-traded sector shrinks to zero, the effect of the import tariff on real government revenue, $s / e$, becomes completely illusory, i.e. $\partial(s / e) / \partial \tau \rightarrow 0$ (cf. Collier and Venables, 2011). In general, the rise in the real value of import tariff revenue is not fully offset by a drop in the real value of oil revenue.

${ }^{17}$ In a context without an explicit natural resource, Mehlum et al. (2020) make free entry into the different sectors endogenous and demonstrate that the economic allocations remain inefficient. We do not allow for free entry. Furthermore, our short cut avoids the need for a principal-agent problem (cf. Grossman and Helpman, 1994).
} 
Hence, the politically motivated tariff is set so that the marginal increase in traded-sector profits plus tariff revenue (allowing for net of erosion of the tariff base) is set to the marginal increase in the cost of living for traded-sector capitalists.

\subsection{Imperfect capital markets}

We suppose that this small open economy has access to international capital markets, so it can borrow bonds at a rate $r$. However, for indebted economies we allow for a risk premium which increases in the debt. To capture this, we assume that the interest that must be paid on foreign debt is $r=\rho$ for economies with foreign assets and $b \leq 0$, and $r=(1+\rho)(1+\Theta(b))-1$ for indebted economies with $b>0$ where $\Theta^{\prime}(b)>0$. Here $\rho>0$ denotes the pure rate of time preference and $\Theta(b)$ the interest premium (cf. van der Ploeg and Venables, 2011). If the interest premium is zero, we have perfect international capital markets. If it is positive, we have imperfect access to international capital markets. Of course, one could argue that an oil or gas discovery increases the wealth and repayment potential and thus the country may be able to borrow more. This may be captured by making the interest premium $\Theta$ a negative function of the size of the oil and gas bonanza (e.g. Mansoorian, 1991) ${ }^{18}$, but no empirical evidence for this has been found (van der Ploeg and Venables, 2011). The reason might be that the country becomes more prone to the resource curse (e.g. van der Ploeg, 2011).

\subsection{Optimal policies in a dynamic setting}

We denote period-one variables by small letters and period-two variables by capitals. The two-period model of Dutch disease and tariffs consists of (1), (2), the future current account condition,

$$
E(P, T) C=Y(P, T)+N-(1+\rho)(1+\Theta(b)) b+T\left[E_{T}(P, T) C-Y_{T}(P, T)\right],
$$

and the condition for equilibrium in the future market for non-tradables,

$$
E_{P}(P, T) C=Y_{P}(P, T) .
$$

where $T$ denotes the future tariff. These equations can be solved for $(c, C, p, P)$ in terms of the policies $(\tau, T, b)$ and the windfalls $(n, N)$. The policies stem from maximising politically distorted welfare, i.e. the present discounted value of utilities of within-period political objective functions $\omega$ and $\Omega$ :

$$
\operatorname{Max}_{\tau, T, b}\left[\omega(n+b, \tau)^{1-\xi}+\frac{1}{1+\rho} \Omega(N-(1+r) b, T)^{1-\xi}\right]^{\frac{1}{1-\xi}},
$$

\footnotetext{
${ }_{18}$ Mansoorian (1991) uses a three-sector Dutch disease model with overlapping generations to show that "excessive" borrowing may result if the extraction of oil and gas is capital intensive. Income may then be shifted away from labour and the country will incur such a large debt that consumption must fall on impact to pay for the interest. But then the economy experiences depreciation of the real exchange rate and pro-industrialisation.
} 
subject to (1), (2), (7) and (8), where $\xi>0$ denotes the constant coefficient of relative intertemporal risk aversion. The optimality conditions for the tariffs are $\partial \omega / \partial \tau=0$ and $\partial \Omega / \partial T=0$ (as discussed in section 3.2). Public debt, $b$, follows from the politically distorted Euler equation

$$
\frac{\Omega}{\omega}=\left(\left(1+\Theta(b)+\Theta^{\prime}(b) b\right) \frac{\partial \Omega / \partial(1+r) b}{\partial \omega / \partial b}\right)^{1 / \xi} .
$$

This Euler equation is distorted in two ways. First, if the economy is indebted and faces a risk premium on debt, there is bias to borrow less and consume more in the future than in the present (due to $\left.\Theta(b)+\Theta^{\prime}(b) b>0\right)$. Second, if the government is concerned primarily in the welfare of tradable sector capitalists rather than aggregate Hicksian consumption, there is another distortion in the Euler equation (due to $[\partial \Omega / \partial(1+r) b] /[\partial \omega / \partial b] \neq 1)$. With only the first distortion but a politically neutral government, $\gamma^{N}=\gamma^{T}=\gamma^{W}$, the Euler equation (10) becomes

$$
\frac{E(N, b) C(N, b)}{e(n, b) c(n, b)}=\left(1+\Theta(b)+\Theta^{\prime}(b) b\right)^{1 / \xi} .
$$

With perfect access to international capital markets, $\Theta=0$, both distortions are absent and equation (11) indicates that it is optimal to smooth consumer expenditure, Hicksian consumption, the cost of living and the real exchange rate, i.e. $c=C, e=E$ and $p=P$, and to have zero tariffs, $\tau=T=0$. However, with imperfect access to international capital markets, an interest rate premium must be paid in the face of an anticipated windfall; in which case, (11) indicates that consumption does not jump up as much in the anticipation period, $e c<E C$, as borrowing is constrained. Notice as well that the lefthand side of (11) increases in $N$ and decreases in $n$ and $b$. We thus see that optimal foreign borrowing, $b(n, N)$, increases in $N$ and decreases in $n$. Hence, to smooth consumption the country borrows ahead of an anticipated windfall but accumulates foreign assets during a temporary windfall.

Our main interest is the politically motivated setting of tariffs. If the government favours owners of capital in the tradable sector over the owners of capital in the non-tradable sector and workers, i.e. $\gamma^{T}>\gamma^{N}=\gamma^{W}$, there may be a rationale for introducing tariffs to protect the traded sector. Furthermore, if access to capital markets is imperfect, tariffs may be introduced to help smooth consumption over time. With capital scarcity, the optimal tariff is then higher during the announcement period than during the windfall so as to achieve better consumption smoothing. We will illustrate this numerically in the next sub-section.

\subsection{Illustration}

Table 1 gives some illustrative numerical policy simulations of our model. We assume Cobb-Douglas production functions for the two sectors with the share of labour $80 \%$ and of capital $20 \%$ of value added, 
i.e. $y^{i}=k^{i 0.2} l^{0.8}, i=N, T$. This gives the labour demand functions $l^{N}=k^{N}(0.8 p / w)^{5}$ and $l^{T}=k^{T}(0.8(1+\tau) / w)^{5}$. Solving for the wage that clears the labour market, i.e. $l^{N}+l^{T}=1$, gives $w=0.8\left(p^{5} k^{N}+(1+\tau)^{5} k^{T}\right)^{0.2}$ and the GNP function $y(p, \tau)=\left(p^{5} k^{N}+(1+\tau)^{5} k^{T}\right)^{0.2}$. For more details, see Appendix C. We assume the expenditure function $e(p, \tau, q)=p^{0.6}(1+\tau)^{0.3} q^{0.1}$, which corresponds to a Cobb-Douglas utility functions with budget shares of non-tradables, tradables and importables of $60 \%, 30 \%$ and $10 \%$, respectively. We could have assumed more general production function or expenditure/utility functions, but the qualitative insights of our model would remain unaltered.

Table 1 shows the outcomes after news of an oil discovery which will lead to an anticipated windfall; the benchmark case corresponds to no windfall (first column in Table 1). The first two outcomes are for a windfall with perfect access to international capital markets. The undistorted case (second column) gives perfect smoothing of consumption and the real exchange rate, which is achieved by borrowing. There is no need to have tariffs. However, if the government gives more weight to capital owners in the traded sector (third column), tariffs are positive and are the same before and during the windfall.

Table 1: Tariffs, borrowing and capital scarcity in face of an anticipated windfall

\begin{tabular}{|l|c|c|c|c|c|}
\hline & \multirow{2}{*}{$\begin{array}{c}\text { No } \\
\text { windfall }\end{array}$} & \multicolumn{2}{l|}{ No capital scarcity } & \multicolumn{2}{l|}{ Capital scarcity } \\
\cline { 3 - 6 } & Neutral & Political & Neutral & Political \\
\hline Profits NT sector & 0.144 & 0.188 & 0.221 & $0.175,0.197$ & $0.207,0.232$ \\
\hline Profits T sector & 0.096 & 0.071 & 0.089 & $0.078,0.066$ & $0.101,0.081$ \\
\hline Wage income & 0.961 & 1.037 & 1.241 & $1.012,1.054$ & $1.230,1.254$ \\
\hline Hicksian consumption & 1.144 & 1.395 & 1.393 & $1.322,1.443$ & $1.313,1.451$ \\
\hline Borrowing & 0 & $\mathbf{0 . 2 7 3}$ & $\mathbf{0 . 2 7 3}$ & $\mathbf{0 . 1 9 1}$ & $\mathbf{0 . 1 8 4}$ \\
\hline Price of non-tradables & 1.084 & 1.216 & 1.450 & $1.174,1.244$ & $1.420,1.474$ \\
\hline Tariff on tradables & 0 & 0 & $\mathbf{0 . 2 0 9}$ & 0 & $\mathbf{0 . 2 2 9 , 0 . 1 9 5}$ \\
\hline Cost of living index & 1.050 & 1.124 & 1.323 & $1.101,1.140$ & $1.313,1.332$ \\
\hline Imports of tradables & -0.120 & 0.116 & 0.088 & $0.046,0.162$ & $0.012,0.145$ \\
\hline
\end{tabular}

Notes: The four columns on the right correspond to an anticipated windfall with $n=0$ and $N=0.6$. The neutral outcome corresponds to $\gamma^{T}=\gamma^{N}=\gamma^{W}=1 / 3$ and the political outcome to $\gamma^{T}=1 / 2>\gamma^{N}=\gamma^{W}=1 / 4$. The cells indicate outcomes for both period 1 and 2 unless outcomes are the same in both periods. We use $\beta^{T}=\beta^{N}=0, \beta^{W}=1, k^{N}=k^{T}=1, \xi=2, q=1$ and $\rho=0.2$. The model with capital scarcity corresponds to $\pi=0.1 b$ and without capital scarcity corresponds to $\pi=0$.

The second two outcomes (fourth and fifth columns) show what happens under imperfect capital markets. For the politically neutral case (column 4), the boosts to consumption and the price of nontradables are smaller before than during the windfall and the government borrows less due to the higher cost of borrowing. With politically distorted preferences (column 5), the tariff is higher before than during the windfall. This alleviates the problem of capital scarcity, curbs borrowing, and explains why the tariff is higher during the announcement period than during the windfall period. 
Our key testable prediction is thus: if the government wants to protect tradable sector capitalists and has imperfect access to international capital markets, it raises tariffs as soon as the news of an oil discovery comes in and partially reverses the tariff once the oil revenue starts to flow. This prediction rests on two assumptions: (i) tradable sector capitalists have more political influence than non-tradable sector capitalists and workers; and (ii) the country has imperfect access to international capital markets. If assumption (i) is replaced by the assumption that workers are politically dominant, we get the opposite effects on tariffs. For example, if $\gamma^{W}=1 / 2>\gamma^{T}=\gamma^{N}=1 / 4$, the political outcome under capital scarcity yields a current tariff of -0.093 and a future tariff of -0.083 and borrowing of 0.194 . Table 1 shows that, if assumption (ii) is replaced by the assumption of perfect capital markets, there is perfect intertemporal smoothing of tariff rates.

\section{Baseline Empirical Analysis}

The above model suggests one possible way how an oil discovery may induce protectionism. It also suggests why the increase in tariffs is partially reversed once oil revenues starts to flow in economies that are subject to credit constraints. It also suggests that these patterns are driven by economies in which the tradable sector is relatively dominant, and capital is scarce. In this section we provide empirical evidence in support of these hypotheses. We do so by employing a framework of country pairs of small open economies that utilises data on bilateral product-level tariffs, and discoveries of giant oil and gas fields. We first describe the data, methodology, and identification strategy. Thereafter, we present our core empirical analysis and results, and then try to give some evidence on the validity of the suggested mechanism of the changes in tariffs following a giant oil or gas discovery.

\subsection{Data and methodology}

Our analysis utilises two primary measures, i.e. oil discoveries and tariffs, in addition to further country, product, and bilateral level covariates. Next, we discuss each of these components in more detail. Further details are provided in Appendices A and B. Descriptive statistics for the key variables are provided in Table 2 for the full sample, and in Table A1 of Appendix A for the samples of economies with and without oil discoveries, separately.

Starting with oil discoveries, we employ data from Horn (2014) on discoveries of giant oil and gas fields, which are defined to be fields for which the estimate of ultimately recoverable oil is at least 500 million barrels of oil or gas equivalent. This data set records the location of all such discoveries across the globe up to 2012. Figure 2 plots the number of discoveries in each of the years in our sample period. Discoveries were made in 29 countries during our sample period. ${ }^{19}$ This group of countries represents both developed and developing economies, with relatively little difference in basic indicators, such as

\footnotetext{
${ }^{19}$ Appendix A lists the countries with at least one giant oil or gas field discovery during our sample period.
} 
income and democracy levels, with the group of countries that had no discovery during the relevant time frame, as outlined in Figures A1 and A2 in the Appendix. Discoveries were made in approximately $9 \%$ of the observations in our sample.

Table 2: Summary statistics of the key variables

\begin{tabular}{|c|c|c|c|c|}
\hline & Mean & Std. Dev. & Min. & Max. \\
\hline $\begin{array}{l}\text { Ad valorem tariff rate (HS-6 level, bilateral, percentage } \\
\text { points) }\end{array}$ & 11.11 & 23.57 & 0 & 3000 \\
\hline Giant oil field discoveries indicator (importing country) & 0.09 & 0.28 & 0 & 1 \\
\hline $\begin{array}{l}\text { NPV of giant oil discoveries in percentage of GDP, realistic } \\
\text { production profile (percentage points) }\end{array}$ & 0.963 & 9.10 & 0 & 193.92 \\
\hline $\begin{array}{l}\text { NPV of giant oil discoveries in percentage of GDP, } \\
\text { constant production profile (percentage points) }\end{array}$ & 1.01 & 10.02 & 0 & 214.59 \\
\hline Democracy level, Polity IV Index (importing country) & 7.84 & 2.14 & 0 & 10 \\
\hline Real GDP per capita ((importing country, real USD) & 10,320 & 12,297 & 141 & 57,455 \\
\hline Trade balance per capita (HS-6 level, bilateral, real USD) & -0.01 & 0.30 & -318.42 & 137.15 \\
\hline Tradables' bargaining position (importing country) & 1.42 & 0.52 & 0.46 & 2.80 \\
\hline Credit constrained (importing country) & 4.44 & 2.42 & 0 & 10.16 \\
\hline $\begin{array}{l}\text { Annual savings per capita (importing country, real USD, in } \\
\text { thousands) }\end{array}$ & 2.73 & 4.18 & -0.63 & 33.51 \\
\hline Average tariff rate (importing country, percentage points) & 11.96 & 7.24 & 0 & 56.73 \\
\hline Annual number of wildcat drillings (importing country) & 21.48 & 48.56 & 0 & 505 \\
\hline
\end{tabular}

Notes: For detailed description of variables, see Appendices A and B. Giant oil field discoveries indicator takes the value 1 in a given year if a discovery occurred in the importing country. Tradables' bargaining position is captured by the interaction of the importer GDP share of exports and its rigidity of employment protection legislation. Credit constrained refer to short term government bond rates (maturity less than 5 years).

Employing data on the discoveries of giant oil and gas fields is appealing. First, it is plausible that their timing is exogenous due to the uncertain nature of oil exploration success. The return on oil exploration is uncertain because of the relatively limited (ex-ante) knowledge of geological features of exploration locations. This feature stands at the heart of our identification strategy. ${ }^{20}$ Second, giant oil fields provide a significant source of oil revenues, especially for smaller economies. ${ }^{21}$ This, in turn, suggests that an oil discovery represents a major economic shock. Following Perez-Sebastian and Raveh (2019), this suggests that once discovered their further development and exploitation are likely to be exogenous to the institutional and economic environment. This is also due to the potentially large profits they provide, which incentivise their continuous operation irrespective of the institutional and economic setting. Third, giant oil field discoveries have a sizeable production lag. Horn (2014) reports that oil production commences, on average, five years following the discovery. ${ }^{22}$ This feature enables us to examine empirically the key predictions of our model concerning the separate effects of oil discoveries and oil production on protectionism.

\footnotetext{
${ }^{20}$ This identification strategy was adopted by previous studies that examined the effects of oil discoveries (e.g. Arezki et al., 2017; Cotet and Tsui; 2013; Lei and Michaels, 2011; Perez-Sebastian and Raveh, 2016). We consider several aspects of this exogeneity assumption, including for instance the potential underlying role of exploration efforts and endogeneity of subsequent discoveries. As an initial step, we include in Figure 2 the evolution of the oil price over time, which does not point at a systematic association with the number of discoveries.

${ }^{21}$ For instance, Arezki et al. (2017) report that the mean value of the GDP share of the net present value of a giant oil field discovery is about $67 \%$ and can get higher than $6000 \%$ (the case of Qatar).

${ }^{22}$ Production can then spread over a period of approximately 50 years, on average.
} 
Figure 2: Discoveries of giant oil and gas fields, and the price of crude oil, 1988-2012

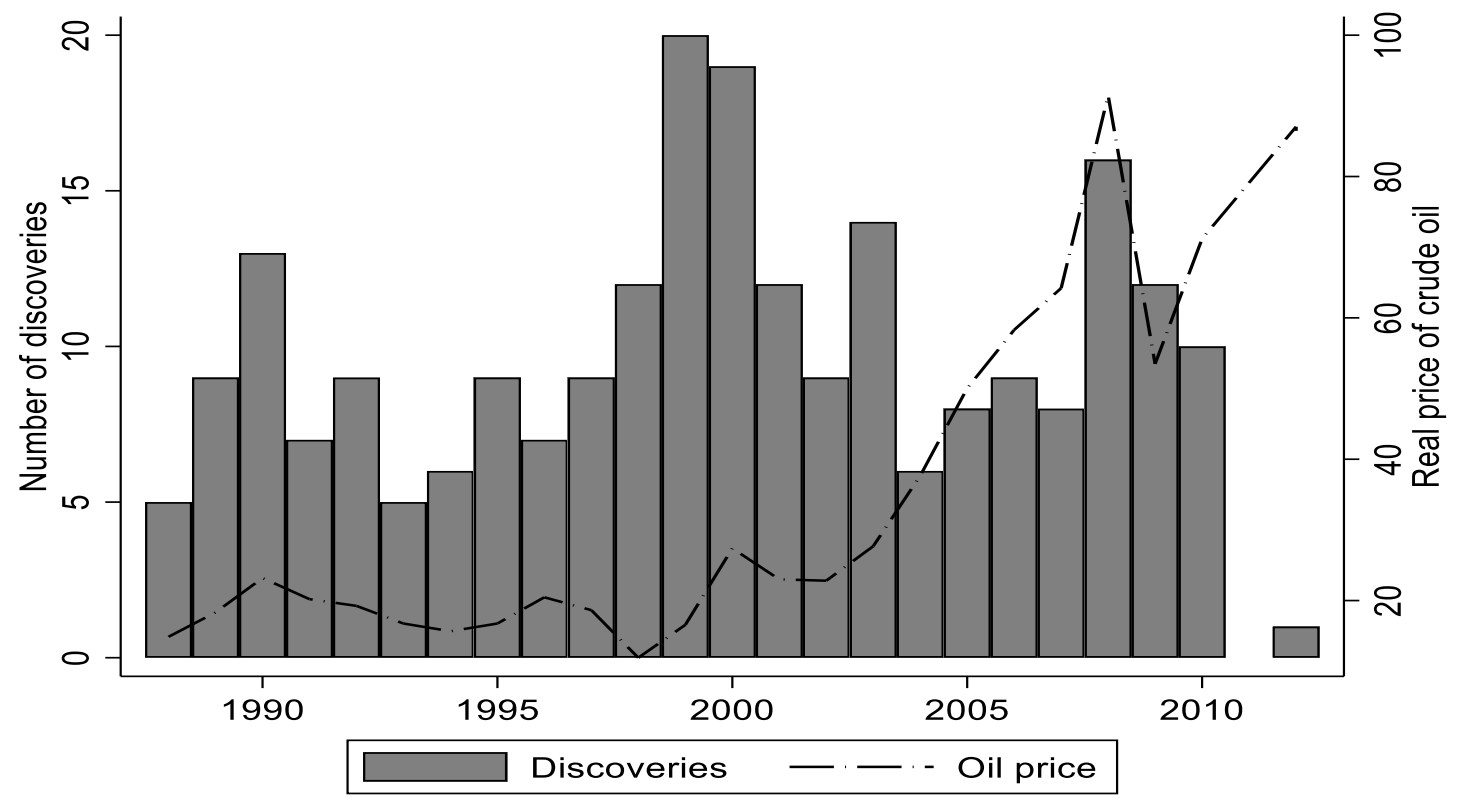

Notes: Figure presents the number of giant oil and gas field discoveries (Source: Horn (2014), and the real price of crude oil (Source: World Bank), 1988-2012.

Next, data on tariffs is retrieved from the World Bank's WITS-TRAINS database. This provides detailed annual-based bilateral ad valorem equivalent tariff data at the product level for a large set of countries, starting in 1988. We utilise the full extent of this rich data set. Our main explanatory measure in the analysis are the bilateral ad valorem tariffs for 5,718 products at the HS-6 level, in 155 small open economies. ${ }^{23}$ Figure 3 plots the average tariff level across our sample period for the group of countries that experienced oil discoveries throughout the given period, and for the group of countries that have not. The plot illustrates the general downward trend in tariffs over time. The average tariff level worldwide in 1988 was around $15 \%$, but by 2012 it has fallen to below $10 \%{ }^{24}$ The trend in tariffs in the two groups is similar, which suggests that the empirical patterns we examine are not an outcome of distinct liberalisation trends. Last, the analysis in addition includes covariates. The ones that are included in all the specifications are real per capita GDP and democracy levels (measured via the standard Polity IV index) of the reporting and partner economies, and the two basic bilateral controls in gravity frameworks, i.e. distance (great circle, i.e. the shortest distance between two points) and the existence of a border (henceforth, controls). These measures control for some of the fundamental determinants of country-level and bilateral tariffs, namely their income level, institutional quality, and proximity to its partner country. ${ }^{25}$ They appear in the specification in the precedent period $(t-1)$, to

\footnotetext{
${ }^{23}$ The complete list of countries included in the sample is outlined in Appendix A. Due to our focus on small open economies, the U.S. and EU economies are excluded from the sample. The EU is also excluded since individual member states cannot unilaterally change tariff rates.

${ }^{24}$ Approximately $20 \%$ of the tariffs are zero. In section 5 we show that the qualitative nature of the changes in tariffs following a giant oil or gas discovery still hold if these tariffs are excluded or if we use Poisson estimation. ${ }^{25} \mathrm{We}$ show in section 5 that the qualitative nature of our results is robust to the exclusion of these controls.
} 
mitigate concerns related to potential endogeneity. Throughout the analysis we employ additional controls at the country, product, and bilateral levels, which we describe separately when discussing the corresponding specification along the analysis.

Figure 3: Import tariffs of economies with oil discoveries VS. those without, 1988-2012

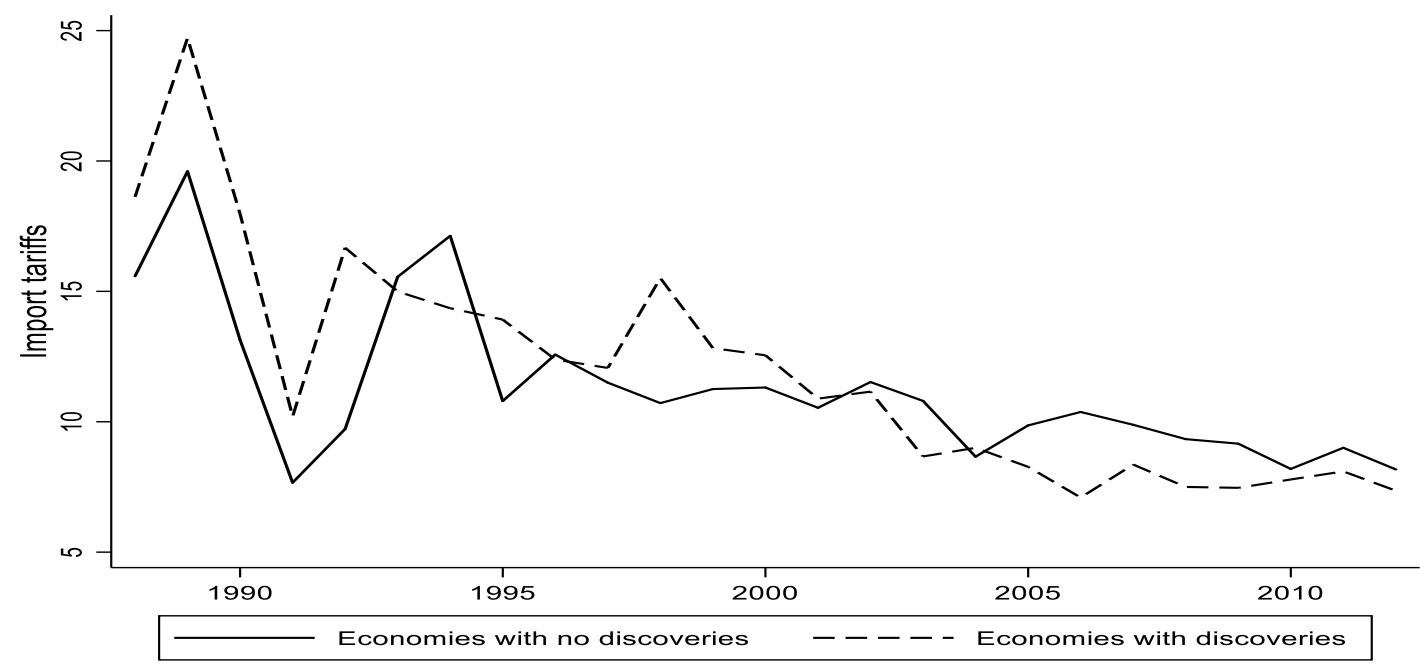

Notes: Figure presents the level of import tariffs of economies with at least one discovery of a giant oil or gas field VS. those without, 19882012 (Source: WITS-TRAINS).

To examine the effect of the exogenous variation in the discovery and exploitation of giant oil and gas fields on bilateral product-level tariffs, we estimate variations of the following fixed-effects model

$$
\tau_{m, x, p, t}=\alpha+\eta \tau_{m, x, p, t-1}+\beta D_{m, t \in[t, t-10]}+\gamma \boldsymbol{X}_{v \in(m, x, p), t-1}+\delta_{m}+\mu_{x}+\pi_{p} * \theta_{t}+\epsilon_{m, x, p, t},
$$

where $\tau$ denotes the tariff rate reported by importing country $m$ (reporter) for product $p \in[1,5718]$ originating from country $x$ (partner) at year $t \in[1988,2012]$, and $\boldsymbol{X}$ is a vector of controls that includes the previously outlined controls in addition to other case-specific measures at the $m, x$, or $p$ levels. Here $\delta, \mu$, and $\pi * \theta$ are importer, exporter, and product by year fixed effects, respectively. These fixed effects control for fixed unobserved heterogeneity at the importer, exporter, and year-specific product levels such as, for instance, product-specific shocks across time or more general global shocks such as changes in the price of oil. Accounting for the latter contributes to identifying the effect of our treatment. The reason is that unobserved variations in demand, supply, and technology changes across products (i.e. potentially important tariff determinants) are controlled for. ${ }^{26}$ In addition, we include the lagged dependent variable. ${ }^{27}$ This enables us to control for the scope of tariff changes as well as estimating the impact on the tariff level relative to its level in the previous period (cf. Arezki et al., 2017).

\footnotetext{
${ }^{26}$ In Appendix E we test different fixed effects settings and show that the main results are robust.

${ }^{27}$ The estimates in this case may be affected by the Nickell bias (Nickell, 1981). However, under the relatively long sample period we adopt, the potential bias of order $1 / T$ is likely to be negligible. In addition, we also examine for robustness in section 5 a specification in which the dependent variable is in changes.
} 
Last is the explanatory variable $D$. This denotes the treatment effect, i.e. the discovery of a giant oil or gas field in the importing country sometime between year $t$ and $t-10$ (depending on the specification). ${ }^{28}$ In our analysis, $D$ is a binary measure that captures the occurrence of a discovery or not. Given that discoveries are defined to be large, we do not exploit further variation related to the more specific (expected) size of the discovery due to the potential measurement errors involved. ${ }^{29}$

We assume that standard errors are correlated within products and importers, and hence are clustered at that level in all specifications. Our primary focus is on the sign, magnitude, and statistical preciseness of the coefficient on $D$, i.e. $\beta$, which provides an estimate of the marginal effect of a giant oil or gas field's discovery on the extent of protectionism, relative to its level in the precedent year. ${ }^{30}$

\subsection{Baseline results}

We start by examining the dynamic effects of oil discoveries on the tariff level over a 10-year period. Such a time frame includes both the pre-production years (years 0 to 4 ) together with the early postproduction ones (years 5 to 10). To do so, we estimate the following version of equation (12):

(13) $\tau_{m, x, p, t}=\alpha+\eta \tau_{m, x, p, t-1}+\sum_{j=1}^{11} \beta_{j} D_{m, t+1-j}+\gamma \boldsymbol{X}_{v \in(m, x, p), t-1}+\delta_{m}+\mu_{x}+\pi_{p} * \theta_{t}+\epsilon_{m, x, p, t}$, where $D_{m, t+1-j}$ is one if a discovery took place in year $t+1-j$ and zero otherwise. The number of observations is 16.2 million, with $\mathrm{R}^{2}$ of about 0.29 . Figure 4 plots the $\beta$ s, together with their $95 \%$ confidence intervals. The results indicate that upon discovery tariffs increase continuously up to the fourth year; however, starting in the fifth year, when production commences and oil or gas revenue starts to flow, tariffs are reduced continuously over the following four years by a lower magnitude than the initial increase, with the reduction wearing off around the tenth year. These patterns provide some initial empirical affirmation for our main hypotheses, as well as for the model's predictions for politically biased and capital scarce economies: prior to the start of oil production tariffs increase but once production commences, this increase in tariffs is partially reversed.

Since we are not interested in the effect of one particular period but in the patterns induced in the discovery years versus those that occur in the post-production period, we next estimate the following benchmark version of equation (12): ${ }^{31}$

$$
\tau_{m, x, p, t}=\alpha+\eta \tau_{m, x, p, t-1}+\beta_{1} \operatorname{Disc}_{m, T}+\beta_{2} \operatorname{Prod}_{m, T-1}+\gamma \boldsymbol{X}_{v \in(m, x, p), t-1}+\delta_{m}+\mu_{x}+
$$

\footnotetext{
${ }^{28}$ While the sample period begins in 1988 , the giant oil field data is available for earlier periods. Hence, $D$ (and additional measures, outlined later, that are based on it) is constructed for the complete sample period, starting in 1988 , despite being based on discoveries prior to the start year of the panel.

${ }^{29}$ Nonetheless, we also test measures that account for the more specific size characteristics of the discovery and show that the main results are not sensitive to using these instead.

${ }^{30}$ The coefficient $\beta_{j}$ gives the marginal impact of a discovery that takes place in period $t+1-j$ on tariffs at $t$. A positive (negative) $\beta_{j}$ suggests that the discovery induces an increase (decrease) in the average tariff level, compared to its previous-period value at $t-1$.

${ }^{31}$ We follow the methodology of Arezki et al. (2017) who examine the effects of aggregate, post-discovery periods to compare more directly the pre- and post-production effects.
} 


$$
\pi_{p} * \theta_{t}+\epsilon_{m, x, p, t}
$$

where $T$ denotes a 5-year period, between $t$ and $t-4$, and equivalently $T-1$ for the precedent 5-year period between $t-5$ and $t-9$; in addition, Disc is a binary variable that indicates whether a discovery occurred during the period $T$, and Prod is a binary variable that indicates whether a discovery took place during period $T-1$. Hence, Disc represents the discovery period (years 0 to 4 from discovery), and Prod the production period (years 5 to 9). ${ }^{32}$ The characteristics of $\beta_{1}$ and $\beta_{2}$ provide an estimate of the distinctive effects of the two periods on the pattern of tariff rates over time. Specifically, each provides an estimate for the average annual marginal effect, in each of the periods. ${ }^{33}$

The results are shown in Table 3. In columns 1 and 2 we include the results of Disc and Prod separately. The estimated $\beta$ 's indicate that tariffs increase in the pre-production years but fall in the post-production ones, in line with the hypothesis put forward in section 3 . The difference in magnitudes suggest that the post-production decrease in tariffs does not cancel the earlier increase in tariffs. Hence, the long-run effect of a discovery of a giant oil or gas field is to increase the degree of protectionism but by less than in the short run.

To better interpret the magnitudes, in column 3 we examine the baseline specification, in which both Disc and Prod are included together (as in equation 14). The signs, magnitudes, and significance are consistent with those obtained under the initial dynamic estimation, presented in Figure 4. The absolute and relative size of the $\beta$ 's indicate that a discovery of a giant oil or gas field on average increases the tariff rate by 0.75 percentage points in each of the first, pre-production five years, and decreases it thereafter by 0.47 percentage points in each of the following five years once production has commenced and revenue is coming in. Hence, overall an oil discovery induces an increase of 1.4 percentage points in the average tariff over the course of 10 years, which amounts to a $13 \%$ increase in the average tariff. This increase is about 2.5 times greater during the discovery period, in which the average tariff increases by 3.75 percentage points (approximately $34 \%$ increase in the average tariff). Conversely, during the post-production period, the average tariff decreases by about 2.35 percentage points (approximately $21 \%$ decrease in the average tariff).

In column 4 we examine whether tariffs respond to the discovery in the pre-discovery period. To do so, we add the binary variable Pre-discovery, which indicates whether a discovery occurred during the period from $t+1$ to $t+4$. This specification examines the patterns of tariffs prior to the discovery, in conjunction with the impact of Disc and Prod. ${ }^{34}$ The coefficient on Pre-discovery in this case is close

\footnotetext{
${ }^{32}$ We focus on a 10-year period in the baseline analysis based on the initial observations, which indicated that the effect of a discovery wears off after about 10 years.

${ }^{33}$ The $\beta$ 's give the average annual marginal effect because the shocks we examine, within the given periods, are annual (as opposed to examining, for instance, the overall average shocks within the timeframe).

${ }^{34}$ Since our sample is capped at 2012, the examination of discoveries that occur up to period $t+4$ restricts the sample size relative to the baseline case.
} 
to zero and is statistically insignificant. The coefficients on Disc and Prod maintain their key characteristics, thus supporting the conjecture that tariffs react to unanticipated discoveries of giant oil and gas fields.

Figure 4: Baseline dynamic patterns, 10-year horizon

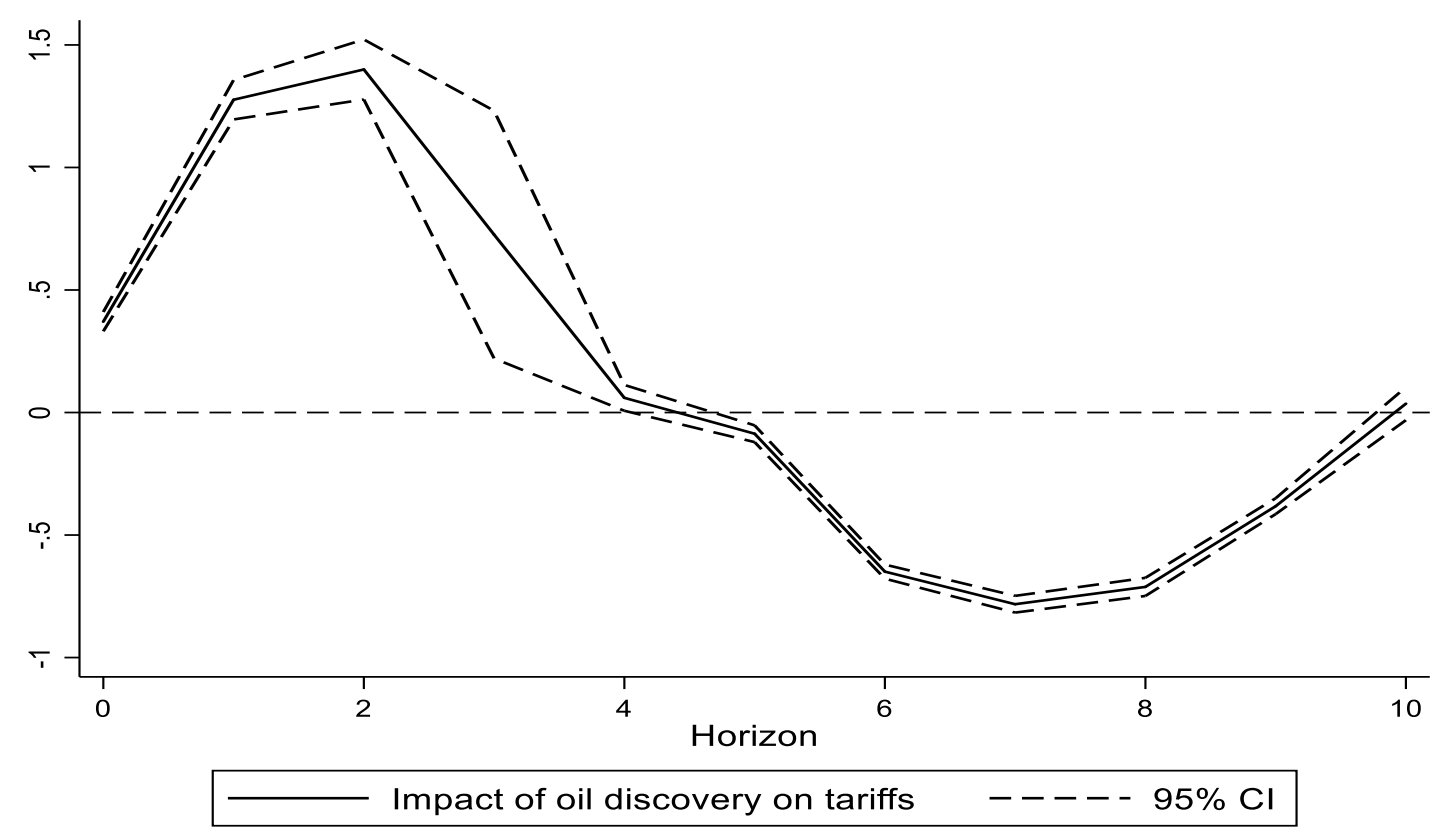

Notes: The figure illustrates the impact of oil discoveries on tariffs over time by plotting the estimated $\beta$ 's from equation (13) with a 95\% confidence interval.

Table 3: Baseline results

\begin{tabular}{c|cccc}
\hline \hline \multirow{2}{*}{ Dependent variable: Tariff rate } & $(1)$ & $(2)$ & $(3)$ & $(4)$ \\
\cline { 2 - 5 } & Discovery & Production & Baseline & $\begin{array}{c}\text { Common } \\
\text { trend }\end{array}$ \\
\hline Discovery & $0.77^{* * *}$ & & $0.75^{* * *}$ & $0.64^{* * *}$ \\
& $(0.07)$ & & $(0.07)$ & $(0.07)$ \\
Production & & $-0.51^{* * *}$ & $-0.47^{* * *}$ & $-0.49^{* * *}$ \\
& & $(0.05)$ & $(0.05)$ & $(0.05)$ \\
Pre-discovery & & & & 0.01 \\
& & & & $(0.01)$ \\
\hline Importer and exporter fixed effects & Yes & Yes & Yes & Yes \\
Product-by-year fixed effects & Yes & Yes & Yes & Yes \\
R-squared, adjusted & 0.29 & 0.29 & 0.29 & 0.29 \\
Observations & $16,242,159$ & $16,242,159$ & $16,242,159$ & $16,011,006$ \\
\hline
\end{tabular}

Notes: Standard errors are robust, clustered by importers and products and appear in parentheses for independent variables. Superscripts $* * *, * * *$ correspond to a 10,5 and $1 \%$ level of significance. Sample includes country pairs of 155 small open economies, across 5718 (6-digit HS codes) products, over the period 1988-2012. The dependent variable is the ad-valorem tariff rate. 'Discovery' ('Production') ['Pre-discovery'] is a dummy variable that indicates whether a discovery of a giant oil or gas field occurred within the precedent 4 years (5 to 9 years) [following 4 years]. All regressions include in addition an intercept, lagged dependent variable, and the following controls (in $t-1$ ): importer/exporter real per capita GDP and democracy levels, bilateral distance (great circle), and an indicator for common border. For further information, see Appendices A and B. 


\subsection{Potential underlying mechanism: tradable sector lobbies and credit constraints}

The baseline results provided some empirical support for the key theoretical predictions, i.e. oil discoveries lead to a short-run increase in the extent of protectionism during the anticipation period and a partial reversal of tariffs once oil production begins. Here we dig deeper into the suggested underlying mechanism. The model proposes a political approach under which the observed patterns are driven by exporters, primarily by dominant political lobbies in the tradable sector and by capital scarce economies. Next, we provide evidence in support of these assertions.

To do so, we estimate the following version of equation (14):

$$
\begin{aligned}
T_{m, x, p, t}= & \alpha+\beta_{1} \operatorname{Disc}_{m, T}+\beta_{2} \operatorname{Prod}_{m, T-1}+\beta_{3}\left(\operatorname{Disc}_{m, T} * C_{\mathbf{z} \in(m, x, p), t-5}\right)+\beta_{4}\left(\operatorname{Prod}_{m, T-1} *\right. \\
& \left.C_{\mathbf{z} \in(m, x, p), t-10}\right)+\beta_{5} C_{\mathbf{z} \in(m, x, p), t-5}+\beta_{6} C_{\mathbf{z} \in(m, x, p), t-10}+\gamma \boldsymbol{X}_{v \in(m, x, p), t-1}+\delta_{m}+ \\
& \mu_{x}+\pi_{p} * \theta_{t}+\epsilon_{m, x, p, t .}
\end{aligned}
$$

Here $C_{z \in(m, x, p), t}$ denotes the measure examined, which changes across the different cases as described below and captures specific characteristics either at the level of the importing country (in which case $\boldsymbol{z}=m$ ) or at the product level (in which case $\boldsymbol{z}=m, x, p$ ). To mitigate concerns related to endogeneity of the measure $C$, we interact it in the year prior to the initial one in each of the discovery and production periods. Hence, in the case of Disc, which concerns the years $0-4$, the interacted $C$ is in $t-5$. In case of Prod, which concerns the years 5-9, the interacted $C$ is in $t-10 .{ }^{35}$ Results appear in Table 4.

First, we motivate the assertion that the demand for protectionism is driven primarily by exporters, and more so by those least exposed to competition by imports. We do this by examining the trade balance at the product level. More specifically, we match the tariff data with bilateral trade volumes at the 6digit HS level for our sample period. ${ }^{36}$ In this case, our variable $C$ in equation (15) is the real partnerby-product specific trade balance (exports less imports) per capita. The results in column 1 indicate that the observed patterns, most notably the tariff increase in the discovery period, appear stronger in products with a favourable trade balance, consistent with the arguments outlined in section $3 .{ }^{37}$ It is also evident that during the oil production years systematic differences are weaker, which supports the negative association between oil revenues and tariffs suggested by the model of section 3 .

Second, we consider the political dominance of the tradable sector by adopting as variable $C$ in equation (15) a simple country-specific interaction measure between the GDP share of total exports of country $m$ and its so-called LAMRIG index level (Campus and Nugent, 2012) in year $t$. The former variable

\footnotetext{
${ }^{35}$ In all cases, data on $C$ commences earlier than our initial year in the sample. Thus, the complete sample period is maintained despite the lags.

${ }^{36}$ This data is retrieved from the UN-Comtrade database. See Appendix A for further details.

${ }^{37}$ Importantly, tariffs are increased in products that are located on the left side of the Laffer Curve for tariff revenues. This is suggested by the analysis carried out in Appendix D, where we examine the impact of oil discoveries on tariff revenues. We find a positive effect. In turn, this also supports the consumption smoothing perspective adopted in the theoretical framework.
} 
proxies for the relative size of the tradable sector in the economy. ${ }^{38}$ The $L A M R I G$ index captures the rigidity of employment protection legislation, and hence the relative political strength of the labour market (e.g. Saint-Paul, 2004). Their interaction provides a proxy for the relative bargaining power of the tradable sector, because large sectors under rigid labour markets may be expected to be economically and politically influential. ${ }^{39}$ The results in column 2 indicate that discovery-induced protectionism is more pronounced in economies with a dominant tradable sector; tariffs seem to be reduced in the post-production period in all economies. These patterns are consistent with those produced under the numerical illustration of the model discussed in section $3 .{ }^{40}$

Table 4: Tradable sector lobbies and credit constraints

\begin{tabular}{c|ccc}
\hline \hline \multirow{3}{*}{ Dependent variable: Tariff rate } & $(1)$ & $(2)$ & $(3)$ \\
\cline { 2 - 4 } & $\begin{array}{c}\text { Trade balance at } \\
\text { product level }\end{array}$ & $\begin{array}{c}\text { Power of } \\
\text { tradable sector }\end{array}$ & $\begin{array}{c}\text { Credit } \\
\text { constraints }\end{array}$ \\
\hline Discovery & $0.75^{* * *}$ & $0.68^{* * *}$ & $0.26^{* * *}$ \\
Production & $(0.07)$ & $(0.24)$ & $(0.05)$ \\
& $-0.48^{* * *}$ & $-1.31^{* * *}$ & $-0.19^{* *}$ \\
Discovery * C__ $t-5)$ & $(0.05)$ & $(0.21)$ & $(0.06)$ \\
& $0.35^{* * *}$ & $0.56^{* * *}$ & $0.08^{* * *}$ \\
Production * C_( $t-10)$ & $(0.09)$ & $(0.12)$ & $(0.01)$ \\
& $-0.15^{*}$ & 0.04 & $-0.06^{* *}$ \\
& $(0.08)$ & $(0.14)$ & $(0.01)$ \\
\hline Importer and exporter fixed effects & Yes & Yes & Yes \\
Product-by-year fixed effects & Yes & Yes & Yes \\
R-squared, adjusted & 0.29 & 0.29 & 0.29 \\
Observations & $16,242,159$ & $16,242,159$ & $16,242,159$ \\
\hline
\end{tabular}

Notes: Standard errors are robust, clustered by importers and products and appear in parentheses for independent variables. Superscripts *, **, *** correspond to a 10, 5 and $1 \%$ level of significance. The complete sample includes country pairs of 155 small open economies, across 5718 (6-digit HS codes) products, over the period 1988-2012. In Regressions 1-3, 'C' represents a measure of the trade balance, tradables' dominance, and financial constraints, respectively (the description of these measures are outlined in the text and data Appendix). The dependent variable is the advalorem tariff rate. 'Discovery' ('Production') is a dummy variable that indicates whether a discovery of a giant oil or gas field occurred within the precedent 4 years ( 5 to 9 years). All regressions include in addition an intercept, lagged dependent variable, and the following controls (in $t-1$ ): importer/exporter real per capita GDP and democracy levels, bilateral distance (great circle), and an indicator for common border. For further information on variables, see Appendices A and B.

Third, we examine the role of credit constraints by considering the country-specific rates of short-term government bonds as our measure $C$ in equation (15). While there are various approaches to measuring the extent of credit constraints, government bond rates represent a useful proxy because they are measured consistently across countries, provide ample cross-sectional and temporal variations, and are available for our sample of economies and years. The results in column 3 indicate that the extent of preproduction protectionism is stronger in capital scarce economies, in line with the proposed mechanism discussed in section 3. Consistent with the previous results, the estimates also indicate that the patterns

\footnotetext{
${ }^{38}$ See Busch and Reinhardt (1999) and references therein for empirical and anecdotal evidence on the relation between market size, bargaining power, and protection.

${ }^{39}$ This measure bears little correlation with either the income level or institutional quality, which suggests that it captures a feature that is applicable in a relatively diverse set of economies.

${ }^{40}$ To the extent that sectoral dominance is associated with the extent of lobbying, these results are consistent with the association between lobbying and protectionism proposed by Grossman and Helpman (1994).
} 
of post-production liberalisation are common to all economies, but are stronger in those that are credit constrained.

\section{Heterogeneous and Sectoral Effects, Timing of Discoveries and Production, and Robustness}

In this section we econometrically investigate richer specifications that our baseline estimates presented in section 4. We first analyse heterogeneous effects for each country depending on differences in real GDP per capita, the degree of democracy, real savings per capita, trade openness and bilateral distance. These give further insights into the potential mechanisms of discoveries and the temporal pattern of tariffs. We then analyse whether the pattern of tariff changes following a giant oil or gas discovery holds at the sectoral level. Finally, we present robustness tests with respect to different lengths of the discovery and production periods and discuss a wide range of additional robustness tests.

\subsection{Heterogeneous effects across countries: digging into potential mechanisms}

To better understand the patterns of tariff changes and dig deeper into the consistency with the proposed mechanism, we next undertake a heterogeneity analysis with some key measures. All cases follow equation (15), yet each outlines a different $C$ variable. The results are shown in Table 5.

In column 1 we test the case of real GDP per capita. The association between trade policy and income has been studied extensively (e.g. Edwards, 1997). We examine its association by interacting it with an oil discovery. The results on $\beta_{1}$ and $\beta_{2}$ indicate that the main patterns still hold, whereas those on $\beta_{3}$ and $\beta_{4}$ suggest that the extent of both the initial protectionism and the later partial reversal of tariff rates are stronger in low income economies. These patterns are consistent with previous evidence on the key role of capital scarcity, given the tight link between the latter and the level of income.

Column 2 investigates the role of the degree of democracy. Cust and Harding (2020) find that exploration efforts are endogenous to the level of institutional quality, so that the latter may be a key underlying channel. To capture democracy, we measure $C$ by the standard Polity IV index which is positively correlated with the extent of democracy. The estimated $\beta$ s suggest that the main patterns on discovery and production still hold. In addition, the heterogeneous impacts point at stronger effects in economies with relatively low levels of democracy. While this may be due to the notion that autocracies may facilitate changes in trade policies due to the centralised institutions and low transparency, this may also follow from the previously discussed credit-constraint channel as this channel may be more prominent in non-democratised economies.

Next, we examine the role of saving. Our analytical model suggests that tariffs increase in economies facing capital scarcity as their attempts to smooth consumption may be frustrated if the option to borrow is limited. Hence, the extent of the estimated patterns of the effects of discoveries on tariffs over time may depend on the ability to save. In addition, saving may be endogenous to oil discoveries (Arezki et al., 2017), and hence may represent a potential transmission channel. We test the viability of these 
points in column 3, in which $C$ represents real saving per capita. While the coefficients on Disc and Prod indicate that the main patterns still hold, the estimates on $\beta_{3}$ and $\beta_{4}$ indicate that the discovery and production patterns are less pronounced in economies in which saving is facilitated.

Table 5: Heterogeneous effects

\begin{tabular}{|c|c|c|c|c|c|}
\hline \multirow{2}{*}{ Dependent variable: Tariff rate } & $(1)$ & $(2)$ & (3) & $(4)$ & $(5)$ \\
\hline & Output & Democracy & Saving & Openness & Distance \\
\hline \multirow[t]{2}{*}{ Discovery } & $1.22 * * *$ & $0.94 * * *$ & $0.94 * * *$ & $0.85 * * *$ & $0.28 * * *$ \\
\hline & $(0.09)$ & $(0.08)$ & $(0.09)$ & $(0.06)$ & $(0.08)$ \\
\hline \multirow[t]{2}{*}{ Production } & $-0.91 * * *$ & $-0.55 * * *$ & $-0.77 * * *$ & $-0.48 * * *$ & $-0.79 * * *$ \\
\hline & $(0.06)$ & $(0.05)$ & $(0.05)$ & $(0.05)$ & $(0.06)$ \\
\hline \multirow[t]{2}{*}{ Discovery $* C_{-}(t-5)$} & $-0.02 * * *$ & $-0.04 * * *$ & $-0.23 * * *$ & $-0.04 * * *$ & $0.06 * * *$ \\
\hline & $(0.002)$ & $(0.004)$ & $(0.08)$ & $(0.01)$ & $(0.004)$ \\
\hline \multirow{2}{*}{ Production * C_( $t-10)$} & $0.006 * * *$ & $0.04 * * *$ & $0.21 * * *$ & 0.008 & $-0.1 * * *$ \\
\hline & $(0.001)$ & $(0.003)$ & $(0.03)$ & $(0.01)$ & $(0.005)$ \\
\hline Importer and exporter fixed effects & Yes & Yes & Yes & Yes & Yes \\
\hline Product-by-year fixed effects & Yes & Yes & Yes & Yes & Yes \\
\hline R-squared, adjusted & 0.29 & 0.29 & 0.29 & 0.29 & 0.29 \\
\hline Observations & $16,242,159$ & $16,242,159$ & $16,242,159$ & $16,242,159$ & $16,242,159$ \\
\hline $\begin{array}{l}\text { Notes: Standard errors are robust, clustered by importers a } \\
\text { ignificance. The complete sample includes country pairs o } \\
\text { output per capita, democracy level, saving per capita, and a } \\
\text { ate. 'Discovery' ('Production') is a dummy variable that in } \\
\text { addition an intercept, lagged dependent variable, and the foll } \\
\text { or common border. For further information on variables, se }\end{array}$ & $\begin{array}{l}\text { Is (in } t-1 \text { ): Impot } \\
\text { A and B. }\end{array}$ & $\begin{array}{l}\text { ses for independent } \\
5718 \text { (6-digit HS co } \\
\text { orting country, respe } \\
\text { tt oil or gas field occ } \\
\text { orter real per capita }\end{array}$ & $\begin{array}{l}\text { bles. Superscripts } \\
\text { products, over the } \\
\text { y (bi-lateral distan }\end{array}$ & $\begin{array}{l}\text { *** correspond to } \\
\text { 1988-2012. In reg } \\
\text { he dependent variab } \\
\text { ears ( } 5 \text { to } 9 \text { years). } \\
\text { lateral distance (gre }\end{array}$ & $\begin{array}{l}5 \text { and } 1 \% \text { level of } \\
\text { ns } 1-4(5) \text { ' } C \text { ' is the } \\
\text { he ad-valorem tarif } \\
\text { gressions include in } \\
\text { le), and an indicator }\end{array}$ \\
\hline
\end{tabular}

In column 4 we test the role of trade openness. Arezki et al. (2019) find that the extent of oil discoveries is endogenous to the degree of market orientation or openness, which may affect the viability and extent of the main effects. More generally, economies that adopt trade-enhancing policies may adjust their extent of protectionism differently than economies that tend to implement greater barriers when facing an oil discovery. To address this, we examine the case in which $C$ is the overall, time-invariant average ad valorem tariff level in the economy as a proxy for the average level of openness and the extent of market orientation. The results indicate that the main intertemporal patterns for changes in tariffs remain to hold, yet the observed increase in the pre-production period is stronger in relatively closer economies. The latter may be a manifest of the greater potential scope that relatively closed economies have for changes in tariffs.

Last, we examine the primary determinant of bilateral trade, namely distance. In column 5 we use our measure of bilateral distance as $C$. The results on $\beta_{1}$ and $\beta_{2}$ are akin to the baseline case, hence the main results for the changes in tariffs over time are robust to this addition. The estimates of $\beta_{3}$ and $\beta_{4}$ indicate that the extent of the effect changes with distance. Specifically, the extent of protectionism increases with distance, and the extent of its reduction during later periods diminishes with distance. These patterns strengthen the motivation behind the adoption of a political approach. While revenues from tariffs may be higher for lower distances, due to the higher trade volumes of proximity, the political cost of implementing barriers may be high. Conversely, if the trade partner is far away, tariff revenues may be marginal, yet the sale of protection may be facilitated if strategic interests weaken with distance. 


\subsection{Effects of giant oil and gas discoveries on tariffs at the sector level}

Next, we test whether the observed patterns of changes in tariffs are different across sectors. To do so, we examine aggregates of the 6-digit HS sectors into the standard 14 main HS sectors, ranging from animal and mineral products to metals and machinery. The list of groups and their composition of 6digit sectors are given in Appendix A. We estimate the baseline specification (column 3 of Table 3 ) for each group separately. The econometric results are shown in Table 6.

Table 6: Sector analysis

\begin{tabular}{|c|c|c|c|c|c|c|c|}
\hline \multirow[b]{2}{*}{ Dependent variable: Tariff rate } & $(1)$ & $(2)$ & $(3)$ & $(4)$ & $(5)$ & $(6)$ & $(7)$ \\
\hline & $\begin{array}{l}\text { Animal } \\
\text { products }\end{array}$ & Foodstuffs & $\begin{array}{l}\text { Mineral } \\
\text { products }\end{array}$ & Chemicals & Plastics & $\begin{array}{l}\text { Raw hides and } \\
\text { leather }\end{array}$ & $\begin{array}{c}\text { Wood } \\
\text { products }\end{array}$ \\
\hline \multirow[t]{2}{*}{ Discovery } & 0.37 & 1.18 & -0.82 & -2.51 & $0.52 * * *$ & $0.71 * * *$ & $-1.78 *$ \\
\hline & $(0.25)$ & $(0.74)$ & $(0.82)$ & $(2.91)$ & $(0.08)$ & $(0.12)$ & $(0.96)$ \\
\hline \multirow[t]{2}{*}{ Production } & $-2.39 * * *$ & $-2.14 * * *$ & $-1.89 * *$ & $-5.94 * * *$ & $-0.12 * *$ & $-0.26 * * *$ & $-0.75 * *$ \\
\hline & $(0.35)$ & $(0.46)$ & $(0.79)$ & $(1.95)$ & $(0.06)$ & $(0.09)$ & $(0.32)$ \\
\hline $\begin{array}{l}\text { Importer and exporter fixed } \\
\text { effects }\end{array}$ & Yes & Yes & Yes & Yes & Yes & Yes & Yes \\
\hline Product-by-year fixed effects & Yes & Yes & Yes & Yes & Yes & Yes & Yes \\
\hline R-squared, adjusted & 0.31 & 0.37 & 0.35 & 0.21 & 0.27 & 0.62 & 0.41 \\
\hline \multirow[t]{2}{*}{ Observations } & 227,805 & 483,358 & 630,941 & 155,667 & $1,711,501$ & 853,646 & 542,911 \\
\hline & $(8)$ & $(9)$ & (10) & (11) & $(12)$ & (13) & (14) \\
\hline Dependent variable: Tariff rate & Textiles & Footwear & $\begin{array}{l}\text { Stone and } \\
\text { glass }\end{array}$ & Metals & Machinery & Transportation & $\begin{array}{c}\text { Optical } \\
\text { apparatus }\end{array}$ \\
\hline \multirow[t]{2}{*}{ Discovery } & $1.24 * * *$ & $0.99 * * *$ & $1.47 * * *$ & $1.07 * * *$ & $2.24 * * *$ & $0.59 * * *$ & $0.47 * * *$ \\
\hline & $(0.14)$ & $(0.09)$ & $(0.24)$ & $(0.13)$ & $(0.19)$ & $(0.07)$ & $(0.07)$ \\
\hline \multirow[t]{2}{*}{ Production } & $-0.36 * * *$ & $0.41 * *$ & $-0.49 * *$ & $-0.31 * * *$ & $-0.41 * * *$ & -0.03 & $-0.45 * * *$ \\
\hline & $(0.09)$ & $(0.16)$ & $(0.23)$ & $(0.1)$ & $(0.11)$ & $(0.07)$ & $(0.09)$ \\
\hline $\begin{array}{c}\text { Importer and exporter fixed } \\
\text { effects }\end{array}$ & Yes & Yes & Yes & Yes & Yes & Yes & Yes \\
\hline \multirow{2}{*}{$\begin{array}{l}\text { Product-by-year fixed effects } \\
\text { R-squared, adjusted }\end{array}$} & Yes & Yes & Yes & Yes & Yes & Yes & Yes \\
\hline & 0.66 & 0.22 & 0.39 & 0.68 & 0.24 & 0.58 & 0.62 \\
\hline Observations & 691,635 & $2,189,180$ & 406,878 & 552,516 & $1,690,901$ & $2,356,886$ & $2,104,039$ \\
\hline
\end{tabular}

Notes: Standard errors are robust, clustered by importers and products and appear in parentheses for independent variables. Superscripts *, **, *** correspond to a 10,5 and $1 \%$ level of significance. The complete sample includes country pairs of 155 small open economies, across 5718 (6-digit HS codes) products, over the period 1988-2012, restricted in each of the regressions to one of the main 15 HS sectors (outlined in the data Appendix). The dependent variable is the ad-valorem tariff rate. 'Discovery' ('Production') is a dummy variable that indicates whether a discovery of a giant oil or gas field occurred within the precedent 4 years (5 to 9 years). All regressions include in addition an intercept, lagged dependent variable, and the following controls (in t-1): importer/exporter real per capita GDP and democracy levels, bilateral distance (great circle), and an indicator for common border. For further information on variables, see Appendices A and B.

Interestingly, the patterns of the effects in tariffs before and after oil production starts are generally similar across sectors. The increase in the extent of protectionism in pre-production years is apparent in most sectors (exceptions are animal products, foodstuffs, mineral products, chemicals, and wood products), and the partial reversal after oil production has started is apparent in the majority of sectors as well (exceptions are footwear, and transportation). The difference lies in the magnitudes. In textiles, stone and glass, and machinery tariffs increase most strongly in the pre-production years; conversely, in animal products, foodstuffs, and chemicals tariffs decrease most strongly in the postproduction years. Notably, over the course of 10 years, oil discoveries increase tariffs in most sectors (exceptions are animal products, foodstuffs, mineral products, chemicals, and wood products).

Overall, the sectors for which the extent of protectionism rises most sharply during the 10-year period are textiles, footwear, and machinery. 


\subsection{Testing different lengths of pre- and post-production periods}

In our baseline analysis we have assumed that the pre-production period is 5 years, based on the average period reported by Horn (2014). Conversely, Arezki et al. (2017) indicate that this period may be shorter or longer, depending on whether the discovered oil field is onshore or offshore. Similarly, the average number of pre-production years may be affected by additional common factors. Hence, we test the robustness of our baseline results to different pre-production periods of 3, 4, 6 and 7 years, respectively. In addition, based on the initial dynamic patterns observed, pointing at an effect that wears off after about 10 years, the baseline analysis examines a 10-year period, out of which the latter 5 years are regarded as the post-production period. Nonetheless, production can spread over several decades. Thus, we also examine cases in which the pre-production period is fixed at its baseline threshold (5 years), and the post-production period is extended to various lengths, from 6 years up to 9 years. The resulting estimates are presented in Table 7.

Table 7: Different lengths of discovery and production periods

\begin{tabular}{|c|c|c|c|c|c|c|c|c|}
\hline \multirow{3}{*}{$\begin{array}{c}\text { Dependent } \\
\text { variable: Tariff } \\
\text { rate }\end{array}$} & (1) & $(2)$ & $(3)$ & (4) & $(5)$ & $(6)$ & $(7)$ & $(8)$ \\
\hline & \multicolumn{4}{|c|}{ Discovery periods } & \multicolumn{4}{|c|}{ Production periods } \\
\hline & 3-year & 4-year & 6-year & 7-year & 6-year & 7-year & 8-year & 9-year \\
\hline Discovery & $\begin{array}{c}1.09 * * * \\
(0.09)\end{array}$ & $\begin{array}{c}0.74 * * * \\
(0.07)\end{array}$ & $\begin{array}{c}0.7 * * * \\
(0.07)\end{array}$ & $\begin{array}{c}0.63 * * * \\
(0.08)\end{array}$ & $\begin{array}{c}0.72 * * * \\
(0.07)\end{array}$ & $\begin{array}{c}0.72 * * * \\
(0.07)\end{array}$ & $\begin{array}{c}0.72 * * * \\
(0.07)\end{array}$ & $\begin{array}{c}0.73 * * * \\
(0.07)\end{array}$ \\
\hline Production & $\begin{array}{c}-0.65 * * * \\
(0.06)\end{array}$ & $\begin{array}{c}-0.53 * * * \\
(0.05)\end{array}$ & $\begin{array}{c}-0.49 * * * \\
(0.05)\end{array}$ & $\begin{array}{c}-0.32 * * * \\
(0.05)\end{array}$ & $\begin{array}{c}-0.43 * * * \\
(0.07)\end{array}$ & $\begin{array}{c}-0.42 * * * \\
(0.05)\end{array}$ & $\begin{array}{c}-0.41 * * * \\
(0.06)\end{array}$ & $\begin{array}{c}-0.37 * * * \\
(0.06)\end{array}$ \\
\hline $\begin{array}{l}\text { Importer and } \\
\text { exporter fixed } \\
\text { effects }\end{array}$ & Yes & Yes & Yes & Yes & Yes & Yes & Yes & Yes \\
\hline $\begin{array}{l}\text { Product-by- } \\
\text { year fixed } \\
\text { effects }\end{array}$ & Yes & Yes & Yes & Yes & Yes & Yes & Yes & Yes \\
\hline $\begin{array}{l}\text { R-squared, } \\
\text { adjusted }\end{array}$ & 0.29 & 0.29 & 0.29 & 0.29 & 0.29 & 0.29 & 0.29 & 0.29 \\
\hline Observations & $16,242,159$ & $16,242,159$ & $16,242,159$ & $16,242,159$ & $16,242,159$ & $16,242,159$ & $16,242,159$ & $16,242,159$ \\
\hline
\end{tabular}

Notes: Standard errors are robust, clustered by importers and products and appear in parentheses for independent variables. Superscripts *, **, *** correspond to a 10,5 and $1 \%$ level of significance. The complete sample includes country pairs of 155 small open economies, across 5718 (6-digit HS codes) products, over the period 1988-2012. The dependent variable is the ad-valorem tariff rate. In regressions 1/2/3/4 'Discovery' ('Production') is a dummy variable that indicates whether a discovery of a giant oil or gas field occurred within the precedent 2/3/5/6 years (3/4/6/7 to 9 years), respectively. In regressions 5/6/7/8 'Discovery' ('Production') is a dummy variable that indicates whether a discovery of a giant oil or gas field occurred within the precedent 4 years $(5$ years to $10 / 11 / 12 / 13)$, respectively. All regressions include in addition an intercept, lagged dependent variable, and the following controls (in $t-1$ ): importer/exporter real per capita GDP and democracy levels, bilateral distance (great circle), and an indicator for common border. For further details on variables, see Appendices A and B.

All cases follow the baseline specification (column 3 of Table 3) but use different Disc and Prod measures. In columns 1-4, the discovery variable (Disc) refers to the period of $t$ to $t-2, t-3, t-5$, and $t-$ 6, respectively, and the production variable (Prod) refers to the period of $t-3, t-4, t-6, t-7$ to $t-9$, respectively. In these cases, a fixed 10-year period is employed, and hence the post-production period ends 9 years after the discovery. The cases differentiate by their division to pre- and post-production periods, within the given 10-year horizon. Columns 1-4, thus, represent the cases of pre- (post)production periods of $3,4,6$, and 7 years (7, 6, 4, and 3 years), respectively. Conversely, in columns 
5-8 the pre-production period (Disc) is fixed at 5 years, similar to the baseline case; however, the postproduction period (Prod) refers to the period of $t-5$ to $t-10, t-11, t-12, t-13$, respectively, equivalent to post-production lengths of $6,7,8$, and 9 years, respectively. Therefore, combining the fixed, 5-year pre-production period and the varying post-production period, columns 5-8 examine extended horizons of $11,12,13$, and 14 years, respectively.

The results indicate that the main patterns are robust to the adoption of different pre- and postproduction period lengths. Notably, in all cases tariffs increase in the pre-production period and decrease thereafter. As expected, the magnitude of the average pre (post) production increase (decrease) drops with the length of the pre-production period as the pre-production period varies, consistent with the dynamic patterns observed initially. In addition, the average post-production decrease in tariffs drops with the length of the post-production period as the post-production period varies, consistent with the assertion that the effects of a discovery are less apparent after 10 years.

\subsection{Additional robustness tests}

We have undertaken a host of robustness tests, which are presented in Appendix E. First, we re-estimate our model with two alternative measures of tariffs and also with two alternative measures of giant oil and gas field discoveries both based on recoverable number of oil barrel equivalents (see Table A.3) and find that the qualitative nature of the pattern of tariff changes following a giant oil discovery (i.e. an increase upon news of a discovery followed by a partial reversal of tariffs once the oil revenue starts to flow) survives. We also find that our results on the pattern of tariff changes is robust to different ways of dealing with zero-tariff entries (excluding zero-tariff entries, excluding zero-import entries, and Poisson estimation), introducing controls for exploration efforts (wildcat drillings), labour market rigidity, common language, coloniser, currency, religion, legal system and bilateral trade indicators (distance and border), allowing for onshore and offshore giant oil and gas discoveries, dealing with potential serial correlation of discoveries, having more general fixed effects (exporter, year, importerby-product, country-pair and product-year fixed effects), and using the change in tariffs as dependent variable (see Table A.4). Furthermore, we had originally used tariff data at a much higher (HS-2) level of aggregation with 96 products in 155 countries over the same sample period, where we also found this pattern for the tariff rates (Perez-Sebastian et al., 2020). At this higher level of aggregation, we found that a giant oil discovery induces a rise of approximately $15 \%$ in the average tariff over the course of 10 years, and that this increase is about 1.8 times larger during the pre-production period when the oil discovery represents a pure news shock.

\section{Conclusion}

We have provided empirical evidence which indicate that oil discoveries represent a key determinant of trade policy formation. More specifically, we have shown that oil discoveries can be a source of 
demand for protectionism before and after the oil production stage. We have also shown that credit constraints and the dominance of the tradable sector matter in tariff policy decisions. Furthermore, our empirical analysis suggests that the protection of the most internationally competitive industries is the main driving force of tariff changes.

To motivate our empirical analysis and understand a potential mechanism underlying our empirical results, we have first set up a political economy model of Dutch disease in which policymakers, knowing the future windfall of oil revenues, choose the path of tariff rates to maximise the weighted sum of the different population groups' utility levels. The model predicts that, if the tradable sector lobby is politically dominant, then the oil discovery induces tariff protection. Moreover, if the economy is also credit constrained, this effect is stronger upon discovery and partially reversed when oil revenue starts to flow. The reason behind the stronger effect during the pre-production stage is the inability to perfectly smooth consumption via judicious debt management.

We have tested these predictions employing bilateral tariff data for 5,718 products in 155 countries over the period 1988-2012, and worldwide discoveries of giant oil and gas fields that can be considered relatively exogenous. Consistent with the theory, the data have supported that an oil discovery raises tariffs during pre-production years and decreases them in the years to follow yet to a lesser extent. Our core estimates suggest that a giant oil field discovery induces a 13\% (approximately 1.4 percentage points) increase in the average tariff over the course of 10 years, and almost 2.5 times this amount during the pre-production period. Our results, thus, indicate that the average tariff increases by about $34 \%$ (3.75 percentage points) during the discovery period, and decreases by about $21 \%$ ( 2.35 percentage points) during the post-production period. These effects are more significant in capital-scarce economies with a relatively dominant tradable sector. These patterns were shown to be robust to a multitude of tests and are quantitatively large.

\section{References}

Arezki, R., A.V. Ramey and L. Sheng (2017). News shocks in open economies: Evidence from giant oil discoveries, Quarterly Journal of Economics, 132(1),103-155.

Arezki, R., F. van der Ploeg and F. Toscanini (2019). The shifting natural wealth of nations: the role of market orientation, Journal of Development Economics, 138, 228-245.

Barsky, R.B., S. Basu and K. Lee (2014). Whither news shocks?, Working Paper No. 20666, NBER, Cambridge, Mass.

Bianchi, J., C. Liu and E.G. Mendoza (2016). Fundamentals news, global liquidity and macroprudential policy, Journal of International Economics, 99, S2-S15.

Beaudry, P and F. Portier (2006). Stock prices, news, and economic fluctuations, American Economic Review, 96(4), 1293-1307.

Beaudry, P. and F. Portier (2014). News driven business cycles: insights and challenges, Journal of Economic Literature, 52 (2014), 993-1074.

Besley, T. and R. Burgess (2002). The political economy of government responsiveness: theory and evidence from India, Quarterly Journal of Economics, 117(4), 1415-1451. 
Busch, M.L. and E. Reinhardt (1999). Industrial location and protection: The political and economic geography of U.S. nontariff barriers, American Journal of Political Science, 43(4), 1028-1050.

Campus, F.N. and J.B. Nugent (2012). The dynamics of the regulation of labor in developing and developed countries since 1960, Working Paper No. 6881, IZA, Bonn.

Caselli F. and G. Michaels (2013). Do oil windfalls improve living standards? Evidence from Brazil, American Economic Journal: Applied Economics, 5(1), 208-38.

Collier, P. and A.J. Venables (2011). Illusory revenues: Import tariffs in resource-rich and aid-rich economies, Journal of Development Economics, 94, 2, 202-206.

Corden, A. and J.P. Neary (1982). Booming sector and de-industrialisation in a small open economy. Economic Journal, 92, 825-848.

Costinot, A., D. Donaldson, J. Vogel and I. Werning (2015). Comparative advantage and optimal trade policy, Quarterly Journal of Economics, 130(2), 659-702.

Cotet, A.M. and K.K. Tsui (2013). Oil and conflict: What does the cross country evidence really show?, American Economic Journal: Macroeconomics, 5(1), 49-80.

Cust, J. and T. Harding (2020). Institutions and the location of oil exploration, Journal of the European Economic Association, 18, 3, 1321-1350.

Daudin, G., R. Christine and D. Schweisguth (2011). Who produces for whom in the world economy? Canadian Journal of Economics, 44(3), 1403-1407.

Edwards, S. (1997). Trade policy, growth, and income distribution, American Economic Review, Papers and Proceedings, 87, 2, 205-210.

Fajgelbaum, D.P., K.P. Goldberg, J.P. Kennedy and K.A. Khandelwal (2019). The return to protectionism, Working Paper No. 25638, NBER, Cambridge, Mass.

Furceri, D., S.A. Hannan, J.D. Ostry and A.K. Rose (2018). Macroeconomic consequences of tariffs, Working Paper No. 25402, NBER, Cambridge, Mass.

Gambetti, L., D. Korobilis, J.D. Tsoukalas and F. Zanetti (2019). The effect of news shocks and monetary policy, Discussion Papers 19-03, Department of Economics, University of Birmingham.

Gawande, K., B. Hoekman, and Y. Cui (2011). Determinants of trade policy responses to the 2008 financial crisis, Policy Research Working Paper Number 5862, World Bank.

Gawande, K. and P. Krishna (2008). The political economy of trade policy: empirical approaches, ub J. Harrigan (ed.), Handbook of International Trade, Basil Blackwell, Oxford.

Harding, T., R. Stefanski and G. Toews (2020). Boom goes the price: Giant resource discoveries and real exchange rate appreciation, Economic Journal, to appear.

Hill, H. (1997). Indonesia's Industrial Transformation, Institute of Southeast Asian Studies, Singapore.

Grossman, G.M. and E. Helpman (1994). Protection for sale, American Economic Review, 84, 4, 833850.

Horn, M.K. (2014). Giant oil and gas fields of the world, available at http://www.datapages.com/AssociatedWebsites/GISOpenFiles/HornGiantFields.aspx.

Jaimovich, N., and S. Rebelo (2009). Can news about the future drive the business cycle?, American Economic Review, 99, pp. 1097-1118.

Keynes, J.M. (1936). The General Theory of Employment, Interest and Money. Macmillan, London.

Kuncoro, A. (2018). Trends in the manufacturing sector under the Jokowi presidency: legacies of past Administrations, Journal of Southeast Asian Economies, 35(3), 402-24.

Lake, J., and M. Linask (2017). Could tariffs be pro-cyclical? Journal of International Economics, 103, 124-146.

Lei, Y., and G. Michaels (2014). Do giant oil field discoveries fuel internal armed conflicts? Journal of Development Economics, 110,139-157.

Leong, W. (2009). Malaysia Catches the Dutch Disease. Centre for Policy Initiatives, http://www.cpiasia.net/v3/index.php/219-contributors-sp-642/contributors/1749-malaysiacatches-the-dutch-disease.

Long, N.V. and N. Vousden (1991). Protectionist responses and declining industries, Journal of International Economics, 30, 1-2, 87-103.

Lorenzoni. G. (2010). Optimal monetary policy with uncertain fundamentals and dispersed information. Review of Economic Studies, 77:305-38. 
Ludema, R.D. and A.M. Mayda (2013). Do terms-of-trade effects matter for trade agreements? Theory and evidence from WTO countries. Quarterly Journal of Economics, 128(4), 1837-1893.

Ludema, R.D., A.M. Mayda and P. Mishra (2010). Protection for free? The political economy of U.S. tariff suspensions, Working Paper WP/10/211, IMF, Washington, D.C.

Mansoorian, A. (1991). Resource discoveries and 'excessive' external borrowing, Economic Journal, $101,409,1497-1509$

Marks, S.V. (2017). Non-tariff trade regulations in Indonesia: Nominal and effective rates of protection, Bulletin of Indonesian Economic Studies, 53(3), 333-57.

McLaren, J. (2016). The political economy of commercial policy, in K. Bagwell and R.W. Staiger (eds.), Handbook of Commercial Policy, vol. 1, part A, pp. 109-159. Elsevier, Amsterdam.

Mehlum, H., K. Moene and R. Torvik (2006). Institutions and the resource curse, Economic Journal, $116,508,1-20$.

Mehlum, H., G. J. Natvik and R. Torvik (2020). The inefficient combination: competitive markets, free entry, and democracy, mimeo., NTNU, Trondheim.

Narayanan, S. 2007. The challenges of raising revenues and restructuring subsidies in Malaysia, Kajian Malaysia, 25(2), 1-28.

Nehru, V. (2012). Indonesian manufacturing and the middle-income trap, East Asia Forum, 7.

Neary, J.P. (1988). Determinants of the equilibrium real exchange rate, American Economic Review, $78,1,210-215$.

Nicita, A., M. Olarreaga and P. Silva (2018). Cooperation in WTO's tariff waters? Journal of Political Economy, 126(3), 1302-1338.

Nickell, S. (1981). Biases in dynamic models with fixed effects, Econometrica, 49, 1417-1426.

Perez-Sebastian, F. and O. Raveh (2016). Natural resources, decentralization, and risk sharing: can resource booms unify nations?, Journal of Development Economics, 121, 38-55.

Perez-Sebastian, F. and O. Raveh (2019). Federal tax policies, congressional voting, and natural resources, Canadian Journal of Economics, 52(3), 1112-1164.

Perez-Sebastian, F., O. Raveh and F. van der Ploeg (2020). Oil discoveries and protectionism, available at SSRN: https://ssrn.com/abstract=3379050 or http://dx.doi.org/10.2139/ssrn.3379050 .

Pigou, A.C. (1927). Industrial Fluctuations. Macmillan, London.

Ploeg, F. van der (2011). Natural resources: curse or blessing?, Journal of Economic Literature, 49(2), $366-420$.

Ploeg, F. van der and A.J. Venables (2011). Harnessing windfall revenues: optimal policies for resource-rich developing economies, Economic Journal, 121, 551, 1-30.

Ploeg, F. van der and A.J. Venables (2013). Absorbing a windfall of foreign exchange, Journal of Development Economics, 103, 229-243.

Pritchett, L. (2000). The tyranny of concepts: CUDIE (cumulated, depreciated, investment effort) is not capital, Journal of Economic Growth, 5(4), 361-384.

Saint-Paul, G. (2004). Why are European countries diverging in their unemployment experience?, Journal of Economic Perspectives, 18(4), 49-68.

Silva, S. and S. Tenreyro (2006). The log of gravity, Review of Economics and Statistics, 88(4), 641658.

Smith, A. (1776). An Inquiry into the Nature and Causes of the Wealth of Nations, Clarendon Press, Oxford.

Tornell, A. and P.R. Lane (1999). The Voracity Effect, American Economic Review, 89(1), 22-46.

Trump, D. (2017). The Inaugural Address, White House, www.whitehouse.gov/Inaugural-address.

Widodo, T. (2008). The structure of protection in Indonesian manufacturing sector, ASEAN Economic Bulletin, 25(2), 161-178.

Wihardja, M.M. (2016). The effect of the commodity boom on Indonesia's macroeconomic fundamentals and industrial development, International Organizations Research Journal, 11(1), 39-54.

WTO (2004). Trade Policy Review - Malaysia, World Trade organization WT/TPR/S/156, Geneva.

Yasar, M. (2013). Political influence of exporting and import-competing firms. Evidence from Eastern European and Central Asian countries, World Development, 51, 154-168.

Yean, T.S. and L.W. Heng (2011). Industrial deepening in Malaysia: policy lessons for developing Nations, Asian Development Review, 28(2), 88-109. 


\section{Appendix A: Data}

We use an annual panel of country-pairs that covers 155 countries, across 5718 (6-digit HS level) products, over 1988-2012 in 2009 prices. Descriptive statistics of the variables for the complete sample are in Table 1. Descriptive statistics for the variables in those countries that had at least one discovery of an oil or gas field during the sample period, versus those that had none, are presented in Table A1.

Table A1-A: Summary statistics of the key variables of economies with a discovery

\begin{tabular}{l|cccc}
\hline \hline & Mean & Std. Dev. & Min. & Max. \\
\hline Ad valorem tariff rate (HS-6 level, bilateral, percentage points) & 13.35 & 30.39 & 0 & 3000 \\
Giant oil field discoveries indicator (importing country) & 0.243 & 0.43 & 0 & 1 \\
NPV of giant oil discoveries in percentage of GDP, realistic & 2.64 & 14.92 & 0 & 193.9226 \\
production profile (percentage points) & & & & \\
NPV of giant oil discoveries in percentage of GDP, constant & 2.76 & 16.4 & 0 & 214.5923 \\
production profile (percentage points) & 7.07 & 2.29 & 1 & 10 \\
Democracy level, Polity IV index (importing country) & 7100.08 & 11075.31 & 302.63 & 56840.84 \\
GDP per capita ((importing country, real USD) & -0.004 & 0.27 & -137.15 & 106.66 \\
Trade balance per capita (HS-6 level, bilateral, real USD) & 1.5 & 0.45 & 0.58 & 2.45 \\
Tradables' bargaining position (importing country) & 5.05 & 2.14 & 0 & 9.93 \\
Credit constrained (importing country) & 2.00 & 4.65 & -0.63 & 33.51 \\
Annual savings per capita ((importing country, real USD, in & & & \\
thousands) & 13.62 & 7.54 & 0 & 52.69 \\
Average tariff rate (importing country, percentage points) & 30.31 & 32.47 & 1 & 148 \\
Annual number of wildcat drillings (importing country) & & & & \\
\hline
\end{tabular}

Notes: For detailed description of variables, see Appendix A.3.

\section{A.1 List of countries in the sample}

Afghanistan, Albania, Algeria, American Samoa, Andorra, Angola, Antigua and Barbuda, Argentina, Aruba, Australia, Austria, Bahamas, Bahrain, Bangladesh, Barbados, Belize, Benin, Bermuda, Bhutan, Bolivia, Brazil, Brunei, Bulgaria, Burkina Faso, Burundi, Cambodia, Cameroon, Canada, Cape Verde, Cayman Islands, Central African Republic, Chad, Chile, China, Colombia, Comoros, Congo, Costa Rica, Cote D'Ivoire, Cuba, Cyprus, Djibouti, Dominican Republic, Ecuador, Egypt, El Salvador, Equatorial Guinea, Fiji, French Polynesia, Gabon, Gambia, Ghana, Gibraltar, Greenland, Grenada, Guam, Guatemala, Guinea, Guinea-Bissau, Guyana, Haiti, Honduras, Iceland, Indonesia, Iran, Iraq, Israel, Jamaica, Japan, Jordan, Kenya, Kiribati, Laos, Lebanon, Liberia, Libya, Madagascar, Malawi, Malaysia, Maldives, Mali, Malta, Mauritania, Mauritius, Mexico, Mongolia, Morocco, Mozambique, Myanmar, Nauru, Nepal, New Caledonia, New Zealand, Nicaragua, Niger, Nigeria, Oman, Pakistan, Panama, Papua New Guinea, Paraguay, Peru, Philippines, Qatar, Rwanda, Saint Kitts and Nevis, Saint Lucia, Saint Vincent, Samoa, Sao Tome and Principe, Saudi Arabia, Senegal, Seychelles, Sierra Leone, Singapore, Solomon Islands, South Korea, Somalia, Sri Lanka, Sudan, Suriname, Syria, Tanzania, Thailand, Togo, Tonga, Trinidad and Tobago, Tunisia, Turkey, Turks and Caicos Islands, Tuvalu, Uganda, United Arab Emirates, Uruguay, Vanuatu, Venezuela, Vietnam, Zaire, Zambia, Zimbabwe.

\section{A.2 List of countries that had at least one discovery of an oil or gas field during the sample period}

Algeria, Angola, Argentina, Australia, Bolivia, Brazil, China, Colombia, Egypt, Equatorial Guinea, Ghana, Indonesia, Iran, Israel, Libya, Malaysia, Mozambique, Myanmar, Nigeria, Oman, Pakistan, Peru, Philippines, Qatar, Saudi Arabia, Thailand, Trinidad and Tobago, Venezuela, Vietnam. 
Table A1-B: Summary statistics of the key variables of economies without a discovery

\begin{tabular}{|c|c|c|c|c|}
\hline & Mean & Std. Dev. & Min. & Max. \\
\hline Ad valorem tariff rate (HS-6 level, bilateral, percentage points) & 11.81 & 18.39 & 0 & 3000 \\
\hline Giant oil field discoveries indicator (importing country) & 0 & 0 & 0 & 0 \\
\hline $\begin{array}{l}\text { NPV of giant oil discoveries in percentage of GDP, realistic } \\
\text { production profile (percentage points) }\end{array}$ & 0 & 0 & 0 & 0 \\
\hline $\begin{array}{l}\text { NPV of giant oil discoveries in percentage of GDP, constant } \\
\text { production profile (percentage points) }\end{array}$ & 0 & 0 & 0 & 0 \\
\hline Democracy level, Polity IV index (importing country) & 0 & 0 & 0 & 0 \\
\hline GDP per capita ((importing country, real USD) & 12123.12 & 12575.10 & 140.82 & 57455.17 \\
\hline Trade balance per capita (HS-6 level, bilateral, real USD) & -0.006 & 0.32 & -318.42 & 137.15 \\
\hline Tradables' bargaining position (importing country) & 1.4 & 0.55 & 0.46 & 2.80 \\
\hline Credit constrained (importing country) & 3.94 & 2.52 & 0 & 10.16 \\
\hline $\begin{array}{l}\text { Annual savings per capita ((importing country, real USD, in } \\
\text { thousands) }\end{array}$ & 3.15 & 3.81 & -0.15 & 19.36 \\
\hline Average tariff rate (importing country, percentage points) & 11.99 & 6.88 & 0 & 56.73 \\
\hline Annual number of wildcat drillings (importing country) & 10.54 & 55.22 & 0 & 505 \\
\hline
\end{tabular}

Notes: For detailed description of variables, see Appendix A.3.

\section{A.3 Variable definitions}

Ad-valorem tariff: The bilateral ad-valorem of 6-digit HS level products. Source: The World Bank's WITS-TRAINS database.

Giant oil or gas field discovery indicator: A binary variable that captures giant oil or gas field discoveries in the importing country. A giant oil or gas field is one for which the estimate of ultimately recoverable oil is at least 500 million barrels of oil or gas equivalent. It may be onshore or offshore. Source: Horn (2014).

NPV of giant oil discoveries: The net present value of giant oil field discoveries, computed by Arezki et al. (2017), under either realistic or constant production profile.

Democracy level: A country's level of democracy measured via the Polity IV index. Source: Polity IV Project, Center for Systemic Peace.

GDP per capita: Real GDP divided by population. Source: The World Bank.

Trade-balance per capita: Real partner and product specific trade balance (exports less imports) at the 6-digit HS level divided by population. Source: UN-Comtrade.

Tradables' bargaining position: The interaction of the partner and product-specific GDP share of exports (Source: UN-Comtrade) and the level of the country's LAMRIG index that captures the rigidity of employment protection legislation (Source: Campus and Nugent (2012)).

Credit constrained: Short-term (with maturities of less than 5 years) government bond rates. Source: The World Bank.

Saving per capita: Real saving divided by population. Source: The World Bank.

Wildcat drillings: The number of wildcat drillings in a country. Source: Arezki et al. (2017).

Bilateral controls: Indicators for having bilateral common language, common coloniser, common currency, common religion, and common legal system. Source: The CEPII database.

\section{Appendix B: Sectoral division}

Group name: aggregated, 6-digit HS, categories included (rounded below to 2-digit).

Animal products: 01-05 ; Foodstuffs: 06-24 ; Mineral products: 25-27 ; Chemicals: 28-38 ; Plastics: 3940 ; Raw hides and leather: 41-43 ; Wood products: 44-49 ; Textiles: 50-63 ; Footwear: 64-67 ; Stone and glass: 68-71 ; Metals: 72-83 ; Machinery: 84-85 ; Transportation: 86-89 ; Optical apparatus: 90-97. 


\section{Appendix C: Functional forms}

We use Cobb-Douglas production functions, $l^{N}=k^{N}((1-\alpha) p / w)^{1 / \alpha}, l^{T}=k^{T}((1-\alpha)(1+\tau) / w)^{1 / \alpha}$, $y(p, \tau)=\left(p^{\frac{1}{\alpha}} k^{N}+(1+\tau)^{\frac{1}{\alpha}} k^{T}\right)^{\alpha}, \quad w(p, \tau)=(1-\alpha) y \quad$ and $\quad y^{N}=y_{p}=k^{N}\left[k^{N}+((1+\tau) / p)^{\frac{1}{\alpha}} k^{T}\right]^{\alpha-1}$. Since $y_{p p}=\frac{1-\alpha}{\alpha} \frac{y_{p}}{p} \frac{((1+\tau) / p)^{\frac{1}{\alpha}} k^{T}}{k^{N}+((1+\tau) / p)^{\frac{1}{\alpha}} k^{T}}$, we have $\varepsilon_{N}^{S}=\frac{1-\alpha}{\alpha} \frac{((1+\tau) / p)^{\frac{1}{\alpha}} k^{T}}{k^{N}+((1+\tau) / p)^{\frac{1}{\alpha}} k^{T}}>0$. Tradables supply $y^{T}(p)=y_{\tau}=k^{T}\left[(p /(1+\tau))^{\frac{1}{\alpha}} k^{N}+k^{T}\right]^{\alpha-1}$ rises in the tariff and falls in the price of nontradables. With Cobb-Douglas utility $\varepsilon^{N}=1-\phi^{N}>0$ and $\varepsilon^{N C}=\phi^{T}>0 .{ }^{41}$

\section{Appendix D: Effect of oil discoveries on tariff revenues}

Our main empirical analysis has focused on the impact of oil discoveries on tariffs. We found that in the pre-production phase tariffs increased primarily in goods that are negligibly imported. The theoretical analysis rationalised these effects by considering political distortions and preferences for consumption smoothing. To test the consistency of the empirical results with the latter, we next examine the impact of oil discoveries on tariff revenues. We construct the latter at the product and country-pair level by interacting the level of ad-valorem tariff with the corresponding value of imports (matched at the HS-6 level). We thus estimate a version of equation (13) in which the dependent variable is the constructed tariff revenues. The results appear in Table A2. In columns 1 and 2 we include Prod and Disc separately while column 3 includes both. The estimated coefficients suggest that tariffs change in products that are on the left side of the Laffer Curve: during the pre-production phase, while tariffs increase, tariff revenues rise; during the post-production phase, when tariffs decrease, tariff revenues fall. These observed patterns lend further support to the proposed theoretical mechanism.

Table A2: Tariff revenues

\begin{tabular}{c|ccc}
\hline \hline Dependent variable: Tariff revenues & $(1)$ & $(2)$ & $(3)$ \\
\hline Discovery & $0.001 * * *$ & & $0.001 * * *$ \\
& $(0.0001)$ & & $(0.0001)$ \\
Production & & $-0.0003^{* * * *}$ & $-0.0002^{* * *}$ \\
& & $(0.00006)$ & $(0.00006)$ \\
\hline Importer and exporter fixed effects & Yes & Yes & Yes \\
Product-by-year fixed effects & Yes & Yes & Yes \\
R-squared, adjusted & 0.66 & 0.66 & 0.66 \\
Observations & $16,310,122$ & $16,310,122$ & $16,310,122$ \\
\hline
\end{tabular}

Notes: Standard errors are robust, clustered by importers and products and appear in parentheses for independent variables. Superscripts *,**, *** correspond to a 10,5 and $1 \%$ level of significance. The complete sample includes country pairs of 155 small open economies, across 5718 (6-digit HS codes) products, over the period 1988-2012. The dependent variable is tariff revenues. 'Discovery' ('Production') is a dummy variable that indicates whether a discovery of a giant oil or gas field occurred within the precedent 4 years (5 to 9 years). All regressions include in addition an intercept, lagged dependent variable, and the following controls (in t-1): importer/exporter real per capita GDP and democracy levels, bilateral distance (great circle), and an indicator for common border. For further information on variables, see Appendices A and B.

\section{Appendix E: Additional robustness}

Here we present various additional robustness tests. We first examine different measures for tariffs and discoveries, and then undertake additional robustness tests.

${ }^{41}$ With CES utility all goods are Hicksian substitutes too. 


\section{E.1. Robustness with respect to different measures for tariffs and discoveries}

Our dependent variable is tariffs and our primary explanatory variable is giant oil and gas field discoveries. Here we examine the robustness of our main results to using different forms of these two measures. In all cases we follow the baseline specification given in column 3 of Table 3. The results are shown in Table A3.

Table A3: Different measures

\begin{tabular}{|c|c|c|c|c|}
\hline \multirow[b]{4}{*}{ Dependent variable: } & (1) & (2) & (3) & (4) \\
\hline & \multicolumn{2}{|c|}{ Tariffs } & \multicolumn{2}{|c|}{ Discoveries } \\
\hline & $\begin{array}{l}\text { Importer by } \\
\text { product }\end{array}$ & Logarithm & $\begin{array}{l}\text { NPV - } \\
\text { projected }\end{array}$ & $\begin{array}{c}\text { NPV - } \\
\text { constant }\end{array}$ \\
\hline & Tariff rate & $\begin{array}{c}\text { Natural } \\
\text { logarithm of } \\
\text { tariff rate }\end{array}$ & Tariff rate & Tariff rate \\
\hline Discovery & $\begin{array}{c}0.75 * * * \\
(0.07)\end{array}$ & $\begin{array}{c}0.06 * * * \\
(0.001)\end{array}$ & & \\
\hline Production & $\begin{array}{c}-0.27 * * * \\
(0.05)\end{array}$ & $\begin{array}{c}-0.06 * * * \\
(0.001)\end{array}$ & & \\
\hline Discovery_NPV & & & $\begin{array}{c}0.09 * * * \\
(0.003)\end{array}$ & \\
\hline Production_NPV & & & $\begin{array}{c}-0.02 * * * \\
(0.001)\end{array}$ & \\
\hline Discovery_NPV_constant & & & & $\begin{array}{c}0.08^{* * * *} \\
(0.002)\end{array}$ \\
\hline Production_NPV_constant & & & & $\begin{array}{c}-0.01 * * * \\
(0.001) \\
\end{array}$ \\
\hline Importer and exporter fixed effects & Yes & Yes & Yes & Yes \\
\hline Product-by-year fixed effects & Yes & Yes & Yes & Yes \\
\hline R-squared, adjusted & 0.29 & 0.88 & 0.29 & 0.29 \\
\hline Observations & $2,822,241$ & $16,242,159$ & $16,242,159$ & $16,242,159$ \\
\hline $\begin{array}{l}\text { Notes: Standard errors are robust, clustered by ir } \\
\text { variables. Superscripts } *, * *, * * \text { ir correspond to a } \\
\text { open economies, across } 5718 \text { (6-digit HS codes) } \\
\text { level, based on pre-discovery trade-based weights) } \\
\text { of the ad-valorem tariff rate (Column } 2) \text {. 'Discove } \\
\text { field occurred within the precedent } 4 \text { years }(5 \text { to } 9 \\
\text { of discoveries [under constant production profile] } \\
\text { lagged dependent variable, and the following cont } \\
\text { (great circle) and an indicator for common border }\end{array}$ & $\begin{array}{l}\text { ters and products } \\
\text { and } 1 \% \text { level of } \\
\text { ucts, over the perii } \\
\text { edependent variab } \\
\text { 'Production') is a } \\
\text { s). 'Discovery_NF } \\
\text { hin the precedent } \\
\text { (in t-1): importer/ } \\
\text { r further informatic }\end{array}$ & $\begin{array}{l}\text { rters in Column } 1 \\
\text { :ance. The comple } \\
8 \text {-2012 (in Colum } \\
\text { e ad-valorem tariff } \\
\text { variable that indi } \\
\text { nstant]' ('Product } \\
\text { (5 to } 9 \text { years). Al } \\
\text { er real per capita } \\
\text { ariables, see Appe }\end{array}$ & $\begin{array}{l}\text { appear in parent } \\
\text { ple includes cou } \\
\text { s is aggregated t } \\
\text { Columns } 1,3,4) \text {, } \\
\text { vhether a discov } \\
\text { PV [_constant }]^{\text {' }} \text { ) } \\
\text { ssions include il } \\
\text { nd democracy le } \\
\text { S A and B. }\end{array}$ & $\begin{array}{l}\mathrm{s} \text { for independent } \\
\text { pairs of } 155 \text { small } \\
\text { importer-product } \\
\text { natural logarithm } \\
\mathrm{f} \mathrm{a} \mathrm{giant} \mathrm{toil} \mathrm{or} \mathrm{gas} \\
\text { net present value } \\
\text { ition an intercept, } \\
\text { bilateral distance }\end{array}$ \\
\hline
\end{tabular}

We test whether our results still hold if two alternative measures of tariffs are used. First, we use a different disaggregation for the ad-valorem bilateral tariff rate by undertaking the baseline estimation under an importer-product-year panel, averaged over all partners with partner-specific weights represented by the share of trade volume in the initial year. Examining a panel under this structure enables us to look into effective changes in protectionism, realising that in certain cases most trade takes place within free trade areas. Second, we test the baseline tariff measure in its natural logarithm form, which allows us to test whether our results are driven by outliers. ${ }^{42}$ The results in columns 1 and 2 suggest that both cases produce patterns in tariff rates, following news of a giant oil or gas discovery, that are qualitatively akin to those obtained in the baseline case.

\footnotetext{
42 To enable transformation for the complete sample, we have added $1 \%$-point to all tariffs prior to conversion.
} 
As for giant oil discoveries, we test the two measures constructed by Arezki et al. (2017). Both are based on the net present value of the giant oil and gas field discoveries, which are computed using the estimated recoverable number of oil barrel equivalents provided by Horn (2014), country-specific discount rates, and underlying production profiles which are either projected or kept constant. The two cases appear in columns 3 and 4, respectively. The results in either case indicate that the main patterns still hold and hence are be robust if these alternative measures of discoveries are used.

\section{E.2. Further robustness tests}

Table A4 reports some additional robustness tests. All cases estimate various variations of the baseline specification (column 3 of Table 3). First, we consider the role of the zero-tariff entries in our sample. Although representing only a quarter of the sample, they may be central to the key results given that they represent partners with free trade and hence potentially little variation in tariffs over time. To examine this, we estimate a sub-sample with the zero-tariff entries excluded, another with zero-import entries excluded, and a third that undertakes a Poisson Estimation of the baseline model (cf. Silva and Tenreyro, 2006). The results in column 1,2, and 3, respectively, indicate that the main results still hold in sign, significance, and magnitude, and hence are not driven by the zero tariff entries in the sample.

Second, we add two additional relevant measures (in $t-1$ ) to the estimated model, to control for exploration efforts and labour market rigidity. Our main identification assumption is that the timing of giant oil field discoveries is exogenous; however, the timing may be a result of exploration efforts, which are endogenous to the economic and institutional setting. Hence, following Arezki et al. (2017), we address that by controlling for exploration efforts via the number of wildcat drillings. Next, Grossman and Helpman (1994) indicate that labour market rigidity may be a key determinant of tariffs, as it may affect the interplay between lobbyists and policy makers; hence, we include the previously discussed $L A M R I G$ index as a proxy for the extent of rigidity in the labour market. The results in column 4 indicate that the main patterns are robust to the inclusion of these additional controls.

Third, we examine the role of the type of giant oil field discoveries. Most discoveries are made offshore, but some are also made onshore. Each type bears its own characteristics, which may affect trade policies. For instance, offshore discoveries are generally larger and may induce international tension due to unclear boundaries of water territories. Hence, in columns 5 and 6 we test sub-samples of onshore and offshore discoveries, respectively. The results indicate that the baseline patterns in changes in tariffs following a giant discovery are observed in both cases. However, they are stronger, both in the initial increase and later decrease in tariffs, for offshore discoveries.

Fourth, we perform an additional test of the underlying identification assumption, i.e. that the timing of discoveries is exogenous. While initial discoveries may indeed be exogenous, oil discoveries may be serially correlated. Consequently, subsequent discoveries may be the result of endogenous indicators, such as exploration efforts or investment in supportive infrastructure. To examine whether this potential concern affects the analysis and results, we exclude from the sample all discoveries that were made subsequently to others. Estimating this restricted sub-sample in column 7, we find that the main results still hold both qualitatively and quantitatively under the exclusion of these subsequent discoveries.

Fifth, in our baseline results we controlled for the two main bilateral trade indicators, i.e. distance and border. We did so to minimise the addition of potentially endogenous measures, which add relatively little explanatory power beyond the two key ones. To test whether this affects the main results, we first add additional bilateral controls, i.e. common language, coloniser, currency, religion, and legal system (all in $t-1$ ), and second exclude the vector of controls (which also includes additional potentially endogenous measures). The results in column 8 and 9 indicate that our baseline results are robust to the inclusion of these additional measures, as well as to the exclusion of the baseline vector of controls.

Sixth, we test the role of additional tariff determinants. Previous studies highlighted the role of comparative advantage (e.g. Grossman and Helpman, 1994; Constinot et al., 2015), product market power (Nicita et al., 2018), and surges in imports and import volatility (Lake and Linask, 2017). To examine whether these determinants affect our baseline results, we estimate a variation of the baseline model which includes exporter, year, and importer-by-product fixed effects, in lieu of the baseline fixed effects employed, and in addition include measures of comparative advantage and import surges. The 
importer-by-product fixed effects control for importer-by-product unobserved time-invariant heterogeneities, including time-invariant product market power and import volatility (proxies examined in Lake and Linask (2017), for instance). Surges in imports are then proxied by the changes in imports in the precedent period, and comparative advantage is proxied by the trade balance, both at the product and country-pair level, matched to the tariffs data as described in sub-section $4.3 .{ }^{43}$ The results in column 10 indicate that our baseline results are robust to the inclusion of these controls.

Seventh, we examine additional specifications, including different fixed effects settings, and a case in which the dependent variable is in changes. Specifically, in column 11 we include country-pair fixed effects instead of the country level ones. In column 12 we exclude the product-year fixed effects to increase the degree of variation examined. In column 13 we test a specification in which the dependent variable is in changes. Notably, the main results still hold in all cases.

Table A4: Additional tests

\begin{tabular}{|c|c|c|c|c|c|c|c|c|c|c|c|c|c|}
\hline \multirow[b]{2}{*}{$\begin{array}{c}\text { Dependent } \\
\text { variable: Tariff rate }\end{array}$} & (1) & (2) & (3) & (4) & (5) & (6) & (7) & (8) & (9) & (10) & (11) & (12) & (13) \\
\hline & $\begin{array}{l}\text { Excluding } \\
\text { zero tariffs }\end{array}$ & $\begin{array}{l}\text { Excluding } \\
\text { zero } \\
\text { imports }\end{array}$ & $\begin{array}{l}\text { Poisson } \\
\text { estimator }\end{array}$ & $\begin{array}{l}\text { Exploration, } \\
\text { and rigidity }\end{array}$ & $\begin{array}{c}\text { Onshore } \\
\text { discoveries }\end{array}$ & $\begin{array}{l}\text { Offshore } \\
\text { discoveries }\end{array}$ & $\begin{array}{c}\text { Non- } \\
\text { sequential } \\
\text { discoveries }\end{array}$ & $\begin{array}{l}\text { Bilateral } \\
\text { controls }\end{array}$ & $\begin{array}{c}\text { No } \\
\text { additional } \\
\text { controls }\end{array}$ & $\begin{array}{c}\text { Tariff } \\
\text { determinants }\end{array}$ & $\begin{array}{l}\text { Country- } \\
\text { pair fixed } \\
\text { effects }\end{array}$ & $\begin{array}{c}\text { No } \\
\text { product- } \\
\text { year fixed } \\
\text { effects } \\
\end{array}$ & $\begin{array}{l}\Delta \text { tariff } \\
\text { rate }\end{array}$ \\
\hline \multirow[t]{2}{*}{ Discovery } & $0.51 * * *$ & $0.73 * * *$ & $0.49 * * *$ & $0.72 * * *$ & & & & $0.74 * * *$ & $0.75^{* * *}$ & $1.14 * * *$ & $0.99 * * *$ & $0.53^{* * * *}$ & $0.75^{* * * *}$ \\
\hline & $(0.07)$ & $(0.07)$ & $(0.06)$ & $(0.07)$ & & & & $(0.07$ & $(0.07)$ & $(0.08)$ & $(0.06)$ & $(0.09)$ & $(0.07)$ \\
\hline \multirow[t]{2}{*}{ Production } & $-0.66^{* * * *}$ & $-0.49 * * *$ & $-0.35^{* * *}$ & $-0.44 * * *$ & & & & $-0.48 * * *$ & $-0.47 * * *$ & $-0.12 * * *$ & $-0.74 * * *$ & $-0.75^{* * *}$ & $-0.47 * * *$ \\
\hline & $(0.05)$ & $(0.05)$ & $(0.05)$ & $(0.05)$ & & & & $(0.05)$ & $(0.05)$ & $(0.05)$ & $(0.05)$ & $(0.06)$ & $(0.05)$ \\
\hline \multirow[t]{2}{*}{ Discovery_onshore } & & & & & $0.49^{* * *}$ & & & & & & & & \\
\hline & & & & & $(0.04)$ & & & & & & & & \\
\hline \multirow[t]{2}{*}{ Production_onshore } & & & & & $-0.16^{* * * *}$ & & & & & & & & \\
\hline & & & & & $(0.01)$ & & & & & & & & \\
\hline \multirow[t]{2}{*}{ Discovery_offshore } & & & & & & $0.25^{* * *}$ & & & & & & & \\
\hline & & & & & & $(0.01)$ & & & & & & & \\
\hline \multirow[t]{2}{*}{ Production_offshore } & & & & & & $-0.34 * * *$ & & & & & & & \\
\hline & & & & & & $(0.01)$ & & & & & & & \\
\hline \multirow[t]{2}{*}{ Discovery_nonseq } & & & & & & & $0.1 * * *$ & & & & & & \\
\hline & & & & & & & $(0.01)$ & & & & & & \\
\hline \multirow[t]{2}{*}{ Production_nonseq } & & & & & & & $-0.26^{* * * *}$ & & & & & & \\
\hline & & & & & & & $(0.01)$ & & & & & & \\
\hline $\begin{array}{l}\text { Importer and } \\
\text { exporter fixed } \\
\text { effects }\end{array}$ & Yes & Yes & Yes & Yes & Yes & Yes & Yes & Yes & Yes & No & No & Yes & Yes \\
\hline $\begin{array}{l}\text { Product-by-year } \\
\text { fixed effects }\end{array}$ & Yes & Yes & Yes & Yes & Yes & Yes & Yes & Yes & Yes & No & Yes & No & No \\
\hline $\begin{array}{l}\text { Country-pair fixed } \\
\text { effects }\end{array}$ & No & No & No & No & No & No & No & No & No & No & Yes & No & No \\
\hline $\begin{array}{l}\text { Product-by- } \\
\text { importer, year and } \\
\text { exporter fixed } \\
\text { effects }\end{array}$ & No & No & No & No & No & No & No & No & No & Yes & No & No & No \\
\hline R-squared, adjusted & 0.28 & 0.31 & $\mathrm{n} / \mathrm{a}$ & 0.29 & 0.29 & 0.3 & 0.29 & 0.29 & 0.29 & 0.51 & 0.29 & 0.23 & 0.29 \\
\hline Observations & $12,574,965$ & $12,330,519$ & $16,242,159$ & $16,242,159$ & $16,242,159$ & $16,242,159$ & $16,242,159$ & $16,099,768$ & $16,242,159$ & $5,686,083$ & $16,241,990$ & $16,245,137$ & $16,242,159$ \\
\hline
\end{tabular}

\section{Appendix F: Malaysia and Indonesia}

The experience of the East Asian economies of Malaysia and Indonesia further illustrate the possible link between natural resource windfalls and protectionist measures, and the importance of political economy. Since the 1970s, the Malaysian economy has relied heavily on natural resource income. In 2004 about 22 percent of industrial output in the country came from minerals, mostly petroleum and natural gas (WTO, 2004). In 2003-2005, new giant oil and gas fields were discovered in the Malaysian territory, and the economy has showed the familiar symptoms of a Dutch disease. In particular, the real exchange rate has appreciated 11 percent from 2005 to 2008, leading to a deterioration of the manufacturing sector's competitiveness. For instance, between 2000 and 2008 the Malaysian trade

\footnotetext{
43 The latter proxy is based on the assertion that a more positive trade balance points at a revealed comparative advantage in the production of the examined product across the specific country-pair.
} 
surplus of machinery and transport equipment went down by 14 percent, while concurrently increasing in other East Asian nations such as China, Singapore, South Korea, and Taiwan. As William Leong (2009), a member of the Malaysian Parliament, has argued, the presence of pressure groups (rent seekers that have privatised and created monopolies in some sectors such as water and electricity) have contributed to this bad performance of the economy. Figure A3 shows that these events coincide with an average increase in the level of protectionism in Malaysia around the time of the giant oil and gas fields discoveries, followed by a wave of liberalisation when oil production commenced around 2009. As evident in the analysis undertaken, these intertemporal patterns are observed under a more general sample of countries when controlling for other explanatory factors and are robust.

Indonesia has experienced multiple and consecutive giant oil field discoveries throughout the 1990s, which make it difficult to assess their impact descriptively. However, Indonesia illustrates that various commodity booms have been accompanied by an increase in protectionist measures due to political pressure generated by groups related to industry. One of those instances is the rapid increase in the price of oil that has led to the oil booms of 1973-74 and 1979-80. Even though strong Dutch disease effects could not be observed due to repeated currency devaluations, the oil boom has still led to reallocation of resources from manufacturing to oil extraction activities. Consequently, the development of some manufacturing industries, like base metals, petrochemicals, automotive and electronics became a policy priority (Kuncoro, 2018). The goal was to use the income from oil extraction to develop sectors in which state-owned enterprises could play a big role. This brought important import substitution policies that included more tariff and non-tariff barriers (Widodo, 2008). The pressure that certain groups have generated to secure protection is important for understanding these increases in trade barriers (Hill, 1977). In the year 2001, palm oil and coal prices rapidly increased causing a new commodity boom in Indonesia that lasted between 2001 and 2012. This time, the symptoms of a Dutch disease were more evident. According to Nehru (2012), the real exchange rate increased by nearly 24 percent between year 2000 and 2012. This caused a partial reversal of Indonesia's successful process of diversification into manufacturing that took place during the 1990s in sectors like chemicals, cements, and machinery, just to name a few (Kuncoro, 2018). The political response was to implement inward-looking policies, protection of domestic markets and industries. For example, Marks (2017) finds that the nominal and the effective rates of protection have increased in Indonesia from 2008 to 2015. Interestingly, Wihardja (2016) argues that these protectionist policies were mainly the results of rent-seeking activities.

Figure A1: Output levels of economies with oil discoveries VS. those without, 1988-2012

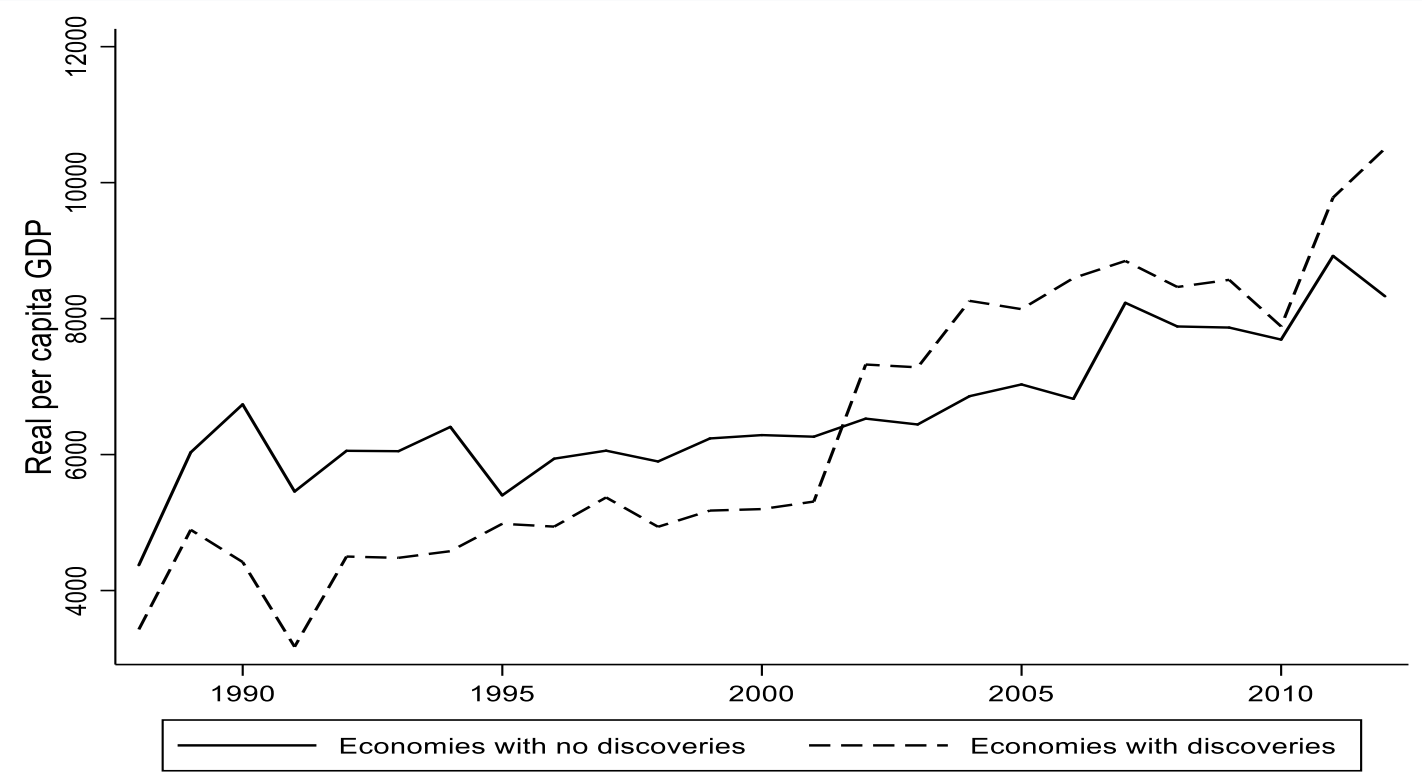

Notes: The figure presents the real per capita GDP of economies with at least one discovery of a giant oil or gas field versus those without, 1988-2012 (Source: World Bank). 
Figure A2: Democracy levels of economies with oil discoveries versus those without, 1988-2012

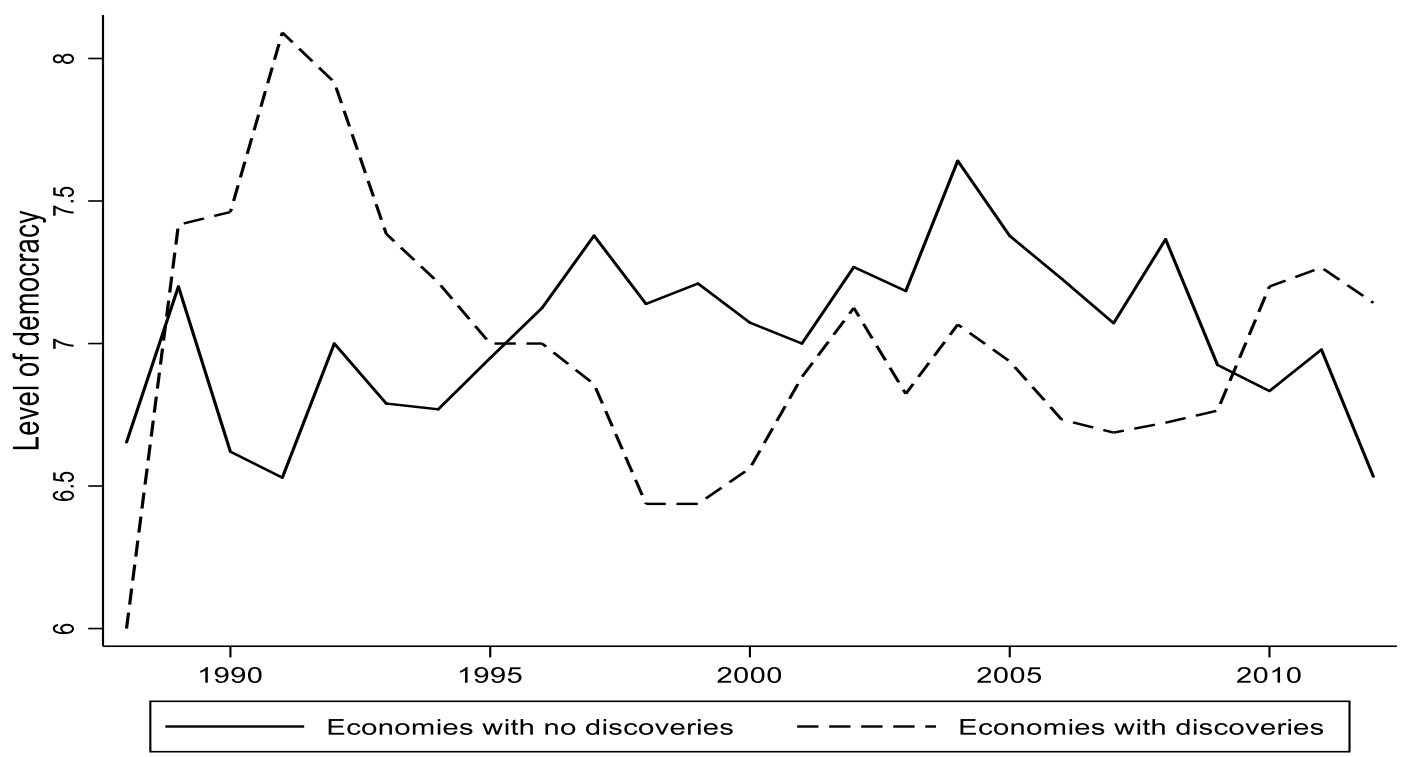

Notes: The figure presents the level of democracy (Polity IV index) of economies with at least one discovery of a giant oil or gas field versus those without, 1988-2012 (Source: Polity IV).

Figure A3: Average tariffs in Malaysia, 1996-2012

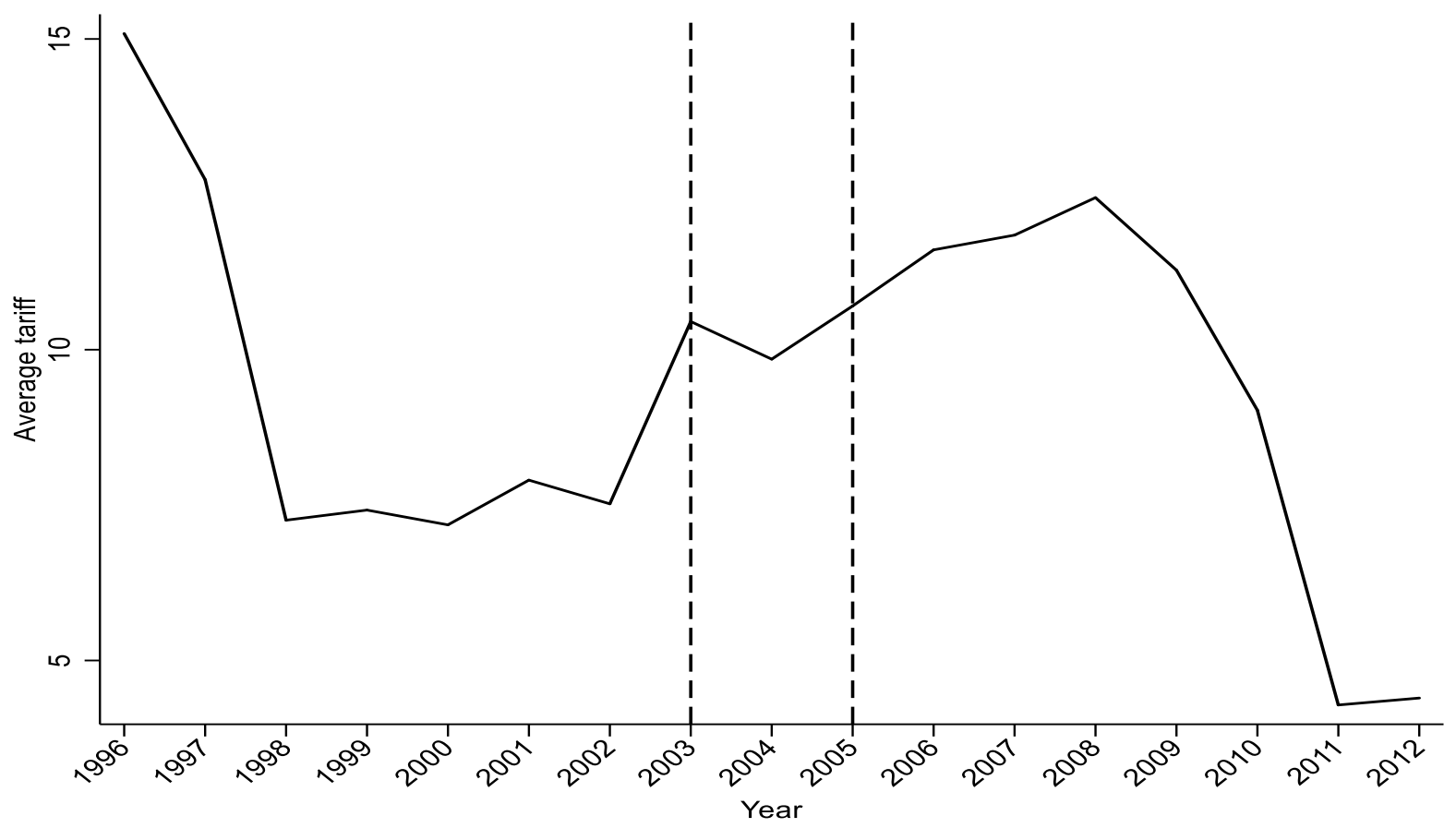

The figure plots the average annual ad-valorem tariffs in Malaysia, 1996-2012. Giant oil fields were discovered in 2003-2005, marked in the period within the dashed lines. 